\title{
Reviewing Theoretical and Numerical Models for PCM-embedded Cementitious Composites
}

\author{
Antonio Caggiano *(D), Christoph Mankel and Eddie Koenders \\ Institut für Werkstoffe im Bauwesen, Technische Universität Darmstadt, 64287 Darmstadt, Germany; \\ mankel@wib.tu-darmstadt.de (C.M.); koenders@wib.tu-darmstadt.de (E.K.) \\ * Correspondence: caggiano@wib.tu-darmstadt.de; Tel.: +49-6151-16-22210
}

Received: 27 November 2018; Accepted: 18 December 2018; Published: 21 December 2018

\begin{abstract}
Accumulating solar and/or environmental heat in walls of apartment buildings or houses is a way to level-out daily temperature differences and significantly cut back on energy demands. A possible way to achieve this goal is by developing advanced composites that consist of porous cementitious materials with embedded phase change materials (PCMs) that have the potential to accumulate or liberate heat energy during a chemical phase change from liquid to solid, or vice versa. This paper aims to report the current state of art on numerical and theoretical approaches available in the scientific literature for modelling the thermal behavior and heat accumulation/liberation of PCMs employed in cement-based composites. The work focuses on reviewing numerical tools for modelling phase change problems while emphasizing the so-called Stefan problem, or particularly, on the numerical techniques available for solving it. In this research field, it is the fixed grid method that is the most commonly and practically applied approach. After this, a discussion on the modelling procedures available for schematizing cementitious composites with embedded PCMs is reported.
\end{abstract}

Keywords: phase change materials; PCM-concrete; thermal behavior; numerical techniques; latent and sensible thermal energy storage

\section{Introduction}

In the last century, the use of cementitious materials, like concretes and mortars, used as a base material for building and construction activities, has grown to vast quantities. The existing building stock, as well as the majority of newly established buildings and infrastructure, are nowadays largely made of reinforced and/or pre-stressed concrete. In the last decades, concrete innovations have been mainly focusing on improvements of the mechanical and durability properties, leading to systems with a high strength, high efficiency, and/or a high performance characteristics. Current endeavours are focussing on innovations that challenge the ability to reuse construction demolishing waste (CDW), saving energy demands while targeting a circular economy [1]. This trend has also been embraced by the concrete industry, which committed itself to reducing its carbon footprint dramatically and turning its "grey" image into a "greener" and more environmentally-friendly one [2]. Therefore, a significant effort still must be done in terms of enhancing the sector's sustainability perspective by reducing its $\mathrm{CO}_{2}$ footprint, widening its recyclability potential, and by cutting back on its energy demands [3].

Climate control and thermal comfort in modern buildings are the main issues that are of paramount importance for controlling and optimizing energy demands, total costs, and, as a spin-off, minimizing $\mathrm{CO}_{2}$ emissions. However, implementing comfortability and, at the same time, sustainability in the new and existing building stock requires cutting edge innovations and efficient engineering systems, which are already the subject of current investigations [4]. Advanced technologies in the concrete industry make it possible to go even a step beyond these ambitions by turning cement-based materials into active thermal energy storing elements [5]. Thermal energy can be accumulated in a construction element using 
sensible, latent, and thermochemical-based materials. Among these, latent heat accumulating polymers, also known as so-called phase change materials (PCMs), are already a preferred solution in various applications. In this context, incorporating PCMs as a thermal energy storage material in construction elements has turned out to be a very efficient way to level out energy needs in modern buildings and/or other infrastructural applications. Due to their ability to absorb and liberate large quantities of latent heat at a constant temperature, PCMs have the potential to reduce the daily energy demand for heating and cooling, with a positive impact on global warming and climate change. Inclusion of PCMs in concrete leads, therefore, to a significant improvement of the material's thermal performance. The efficiency to store thermal heat in a PCM-concrete makes it interesting to investigate the properties that allow for a wider use in construction and building applications [6,7].

Numerous different kinds of PCMs are being used in the literature. According to their chemical composition, they can be categorized as organic (O) compounds (paraffin and non-paraffin), inorganic (I) compounds (salt hydrate and metallic), and eutectic mixtures (O-O, I-I, I-O). PCMs can also be identified by their mode of phase transition: Liquid-gas, solid-gas, solid-liquid, and solid-solid. On the one hand, applications of both solid-gas and liquid-gas are limited in thermal storage capacity due to their large volume change, mainly associated with the gas state. On the other hand, the sensible heat capacity of solid-solid transitions is considerably lower than solid-liquid PCMs. For these reasons, in general, solid-liquid PCMs are preferred in thermal energy storage [8]. Other classifications of PCMs can be based on their thermal properties (e.g., melting temperature range, latent heat per unit volume, specific heat for sensible storages, thermal conductivity of their phases, etc.). For example, based on their temperature ranges, PCMs can be subdivided into low temperature PCMs (melting point below $10 / 15^{\circ} \mathrm{C}$ ) employed for cold applications, mid temperature PCMs (melting point between $15 / 80{ }^{\circ} \mathrm{C}$ ) suitable for applications in building design, and finally, high temperature PCMs (melting point over $80^{\circ} \mathrm{C}$ ), normally used for industrial applications, like solar energy power plants [9].

A wide range of applications deal with the use of PCMs for enhancement of the thermal comfort of buildings and constructions. PCMs can be integrated in structural or non-structural elements for improvement of the thermal efficiency and sustainability in buildings in terms of cooling, heating, or both [10]. They can also be employed through passive or active systems for heating/cooling exchangers. In passive systems, the release of heating or cooling energy only depends on the environmental temperature fluctuations. These applications can easily be implemented in building frames, like walls, roofs, and/or floors, without any mechanical interference needed for changing or discharging heat. Contrarily, active systems do need a mechanical action to charge/discharge accumulated heat energy in PCMs [11].

Firstly, in Section 2, this state of the art document reports an overview of the available scientific literature on thermal energy storage and accumulations using PCMs. Section 3 reports a short discussion of the various experimental campaigns used for PCM-concretes, then, in Section 4, a discussion is addressed that focuses on a review of the various numerical tools used for modelling phase change problems, while emphasizing the so-called Stefan problem. Further details about the fixed grid method, adopted as the most common and practical approach for modelling the Stefan problem in PCMs, are described in Section 5. Then, Section 6 focuses on reviewing the available modelling procedures for cementitious composites enclosing PCMs based on different scale approaches (structural-, macro-, meso-, and microscale procedures). Finally, concluding remarks and an outline of future research steps to cover the observed research gap on numerical simulations of phase-change materials and processes in PCM-concretes will be reported in Section 7.

\section{Review on Thermal Energy Storage Using PCM}

Numerous articles on phase change materials have been reported in the literature in several fields of applications, with most of them of a scientific nature. Among several of them, the state of art of PCMs was explicitly addressed for emphasizing the use of thermal energy storage in various 
engineering and practical applications. These turned out to be very helpful for understanding the state of current research, and to determine the direction of future research steps for PCM developments.

This section reviews the available papers that use PCMs as a sensible latent storage system. Particularly, Table 1 highlights those articles that explicitly address PCMs for thermal energy storages (TESs) usage. Until now, 23 works [9,12-33] were found that deal with the use of PCMs as TES from a general perspective, such as industrial applications, buildings and construction elements, heating/cooling of water, solar energy plants, biomaterials and biomedical applications, electronic, automotive industry, food industry, etc. These articles focused on several aspects concerning the way TES was achieved by adopting PCMs, while accounting for different topics and/or focus areas, such as PCM types and classifications, sensible vs. latent TES in various amounts of PCMs, melting points, porous containers for PCMs, measurement techniques, experimental analysis, numerical tools and mathematical modelling, thermal conductivity enhancements, encapsulation methods, long term and cycle responses, cases studies, and applications.

Table 1. Latent heat storages with PCMs: General and buildings applications.

\begin{tabular}{|c|c|c|}
\hline Ref. & & Main focus and reviewed topics \\
\hline [9] & & Sensible vs. latent TES - PCMs types and classification - Applications in several fields - Fire retardation in construction and buildings \\
\hline [12] & & PCMs types and classification - Melting points - PCM containers - Applications in several fields - Numerical, experimental and analytic solutions \\
\hline [13] & & PCMs classification and methods - Thermal conductivity enhancements - Microencapsulated PCM - Mathematical modeling of LHTS systems \\
\hline [14] & & LHSs - PCMs classification - Measurement techniques - Melting T - TES systems in several fields of application - Numerical approaches \\
\hline [15] & PCMs for Therma Enerov Storage (TES) & PCM types - Thermal conductivity enhancers - Fire hazard treatment of paraffin - PCM textiles and clothing with PCM for cold environmeant \\
\hline [16] & C Mis Tor Thermal Energy storage (IES) & PCMs classification and properties - Encapsulation methods - Main applications of PCMs in several fields \\
\hline [17] & & PCMs classification - Thermophysical properties and long term stability - Heat transfer: theory and simulation - Applications in several fields \\
\hline $\bar{g}[18]$ & & Sensible heat storage systems - Latent heat storage systems - Chemical heat storage systems - Thermal properties \\
\hline$\sum_{E}^{[19]}$ & & Ultrafine phase change fibers - Electrospinning PCMs - Thermal properties \\
\hline$\frac{\underline{n}}{\pi}[20]$ & & Thermal conductivity enhancement - Thermal properties - PCMs applications \\
\hline [21] & & Phase change materials with melting points above $300^{\circ} \mathrm{C}$ - Solar power plants applications \\
\hline$\sum[22]$ & & Energy storage systems - High temperature thermal energy storage materials - Modelling \\
\hline [ $[23]$ & High temperature thermal energy storage & Thermal energy storage applied to solar power plants and case studies \\
\hline हुّ [24] & & PCMs - Storage of thermal and solar energy in the range of temperatures from 120 to $1000^{\circ} \mathrm{C}$ \\
\hline 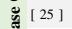 & & Thermophysical properties of PCM - Material selection - Heat transfer enhancement \\
\hline [26] & & PCMs and classifications - Heat transfer enhancement methods - Solar passive and active space heating systems - Greenhouses - Solar cooking \\
\hline [27] & & Classification of solar energy collectors - Classification - Storage types: latent vs. Sensible \\
\hline [28] & Solar TES with PCM & TES technologies - Individual pros and cons - Space and water heating applications \\
\hline [29] & & Heat transfer enhancements - Solar energy systems - Energy and exergy analyses of TES \\
\hline [30] & & Phase change materials for solar TES - Solar photovoltaic for buildings \\
\hline [31] & Encapsulation of PCM & Requirements of LHTS - Encapsulation of PCM: Bulk storage, Macro- and Microencapsulation - Heat transfer studies and applications \\
\hline [32] & Microencapsulation (M) of PCM & MPCM - Characterization - Encapsulation size - Shell thickness, materials and encapsulation geometry \\
\hline [33] & PCM for cold applications & Potential of PCM at low temperatures (less than $20^{\circ} \mathrm{C}$ ): ice storage - conservation/transport of sensitive materials - air conditioning - cold stres \\
\hline [10] & & Major applications - Active and passive methods - Thermal confort in buildings \\
\hline [34] & & Comparative analyses using small laboratories data - Plenty of experimental data in reals size rooms \\
\hline [35] & & PCM materials - Building applications - Current technology and further researches \\
\hline [36] & & PCM classification and properties - Incoporation techniques - Thermal properties of PCM and PCM-composites - Building applications \\
\hline [37] & & TES materials - Sensible, Latent and Thermochemical-based materials for building applications \\
\hline [38] & & PCMs and thermal proprieties - Inclusion of PCMs in buildings elements - Numerical tools \\
\hline [39] & & PCM materials - Building applications -Thermal properties - Enhancement solutions \\
\hline [40] & & Study and classification of PCM applications - PCM active applications / passive applications - PCM numerical simulations and experiments \\
\hline [41] & & PCM for heating and cooling in buildings - Micro and Macro encapsulations - Application in buildings with several techniques \\
\hline [42] & & PCM materials - Thermal properties, enhancements - Impregnation in construction materials - Applications - Numerical simulation for buildings \\
\hline$[43]$ & & Passive building concepts (heating and cooling) - Latent heat storage of PCMs - Building and constructions - Humidity-controlled materials \\
\hline 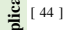 & PCM for TES in buildings & PCM - Thermal properties - Long term stability - Encapsulation - Fire retardation in construction materials - Heat transfer enhancements \\
\hline (25] & & PCMs and combination techniques - Measuraments of thermal proprieties- Experimental and numerical researches \\
\hline है $[46]$ & & PCMs and thermal proprieties - Test methods for PCM - Building applications - PCM in concrete \\
\hline$[47]$ & & PCMs in buildings for free cooling / for peak load shifting - Active building systems - Passive building systems \\
\hline $\bar{a}[48]$ & & Passive building concepts (heating/cooling) - PCMs thermophysical properties - candidates PCM for buildings - Applications in buildings \\
\hline $\bar{a}[49]$ & & PCM and classifications - Heating/cooling of buildings - PCM incorporation in building materials - Active / - Passive building systems \\
\hline$\sum_{0}[50]$ & & Passive building concepts (heating and cooling) - Active PCMs for space heating and cooling - Major applications in buildings \\
\hline$[51]$ & & Passive building concepts (heating and cooling) - PCMs thermophysical properties - candidates PCM - Applications in buildings \\
\hline 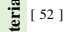 & & PCMs and developments - Encapsulation in structures - Micro/Macro encapsulation methods - Fire retardation \\
\hline$\sum^{\frac{\pi}{2}}[53]$ & & Phase Change Materials for energy saving and management in greenhouses \\
\hline$[54]$ & & Building envelope - Building equipments - Energy performance - Thermal comfort - Thermal energy storage \\
\hline [55] & & Energy efficiency in buildings - Mortar PCM - Thermal properties - Structural properties \\
\hline$[11]$ & & PCM techniques in building applications - Topology scheme for the choice of the candidate PCM for cooling systems \\
\hline 总 $[56]$ & & Organic, inorganic and eutectic PCMs - Passive cooling in buildings - Major applications \\
\hline [57] & & Free cooling - Application, parameters and feasibility - Numerical techniques: temperature-based heat capacity method, enthalpy formulation \\
\hline [58] & applications & PCMs for free cooling - Passive cooling techniques - Heat transfer problems - Design considerations \\
\hline [59] & & PCMs characteristics and classification - PCM cooling system - Free cooling - Air condition/Ventilation - Encapsulated PCM in walls and bricks \\
\hline [60] & & \\
\hline [61] & & Free coo \\
\hline [62] & & CMs and Stefan problem - Fixed grid methods: Enthalpy-, \\
\hline $\begin{array}{l}{[63]} \\
{[64]}\end{array}$ & Theoretical and numerical tools & Ms and Stefan problem - Fix \\
\hline$\left[\begin{array}{l}{[64]} \\
{[65]}\end{array}\right.$ & Microencal & \\
\hline [66] & buildings & $\begin{array}{l}\text { MPCM-Characterzation - Bulding applications - Case studies } \\
\text { MPCM - Building applications - Concrete }\end{array}$ \\
\hline [67] & Thermal sta & Physical properties - Repeated thermal cycles - Ther \\
\hline 68. & Ther & \\
\hline
\end{tabular}


Moreover, 37 articles [10,34-68] dealt with PCMs for building applications. Among them, 23 referred to the available studies and research aimed at controlling the thermal comfort in buildings by means of PCMs [10,34-55], seven focused on the employment of PCMs mainly in cooling applications [11,56-61], three were fully dedicated to the available theoretical models and numerical tools for modelling PCMs and PCMs in building applications [62-64], two were on microencapsulated (M)-PCM $[65,66]$ in buildings, and, finally, the last two articles were on the thermal stability and thermal conductivity enhancement of PCMs $[67,68]$. The reviewed papers on PCMs in buildings, using latent thermal energy storage systems, covered several topics ranging from passive to active systems, heating and cooling applications for thermal comfort, experimental studies, small laboratory studies and full-size room tests, incorporation and impregnation techniques, PCM-concretes, sensible, latent and thermochemical-based PCMs for construction, enhancement solutions, micro and macro encapsulations, long term stability and cycle behavior, fire retardation in construction materials, the Stefan problem and numerical models, temperature-based heat capacity method, enthalpy formulations, fist law and second law based models, model collections, etc.

\section{Experimental Investigations on PCM-Concretes}

This section reports a short overview on the available experimental studies on PCM-concrete systems. The review is elaborated in a very broad way, thus, considering all applications with organic and inorganic PCMs. However, it may be worth mentioning that most PCM-concrete applications employ paraffin-based (organic) materials and only a few refer to other phase-change materials.

Numerous experimental-based research, available in the literature, addressed the hydro-thermochemo-mechanical properties of cementitious materials containing PCMs. Whenever PCMs are embedded in concrete used for passive heat storage in residential buildings, they are characterized by their melting temperature, which varies between $18{ }^{\circ} \mathrm{C}$ and $25^{\circ} \mathrm{C}$, which somehow corresponds to a standard temperature range for comfortable living [34]. PCMs employed in concrete can be of an organic (paraffin and non-paraffin) and/or inorganic (hydrated salts) nature [69]. The organic PCMs that are commonly employed for concrete are paraffin waxes, which are characterized by a very large latent thermal heat storage density, have little (or quasi absent) undercooling, low vapor pressure, are soundless, thermal and chemical stable, show a lack of phase separation, have a self-nucleating behavior, have adaptable phase change temperatures, are environmentally harmlessness, have no unpleasant odor, are non-toxic, and are economically attractive [70]. Despite this, one of the critical points that needs attention is the low thermal that conductivity paraffin waxes have, which reduces the pace at which heat can be stored and/or released during a melting and crystallization phase change operation [71]. Furthermore, another weak aspect is the density change that occurs during a heating/cooling cycle (i.e., which runs in both ways, i.e., through a melting/solidification as well as through a solid/liquid phase change), and which causes a change of its actual volume to a large extent [70].

Four typical methods for incorporating PCMs in concrete are distinguished: i.e., (i) immersion of porous concretes/mortars, (ii) direct mixing of micro-encapsulated (M-)PCMs, (iii) macroencapsulation, and (iv) aggregate impregnation.

The first technique is based on the immersion of liquid PCM into the dried open pore space of a cementitious composite, where the effectiveness of it depends on the permeability/absorption capacity of the porous medium, the operating temperature, and the type of the employed PCM. These aspects may strongly affect the timespan needed to fully immerse the concrete. The method is thus suitable for concrete bricks, blocks, or wallboards, which are capable of absorbing large amounts of PCM; however, leakage problems, especially after various thermal cycling, may occur that may impact the environment and flammability of the final product, which implicitly represents the main drawbacks of this method. Experimental works investigating this technique were published by [72-75].

Direct mixing of microencapsulated PCMs in concrete and mortars are proposed in many articles. M-PCM are thin shell-based particles containing PCMs, and are proposed to be mixed in a concrete 
while avoiding leakage phenomena, and, at the same time, increasing the fire resistance of the microencapsulated PCM [76]. However, it may be worth mentioning that M-PCMs may lower the mechanical properties of a concrete, especially when particles are broken during the mixing and/or for high dosages [52]. M-PCMs in Portland cement concrete and geopolymer-concrete (GPC) were investigated in [77]. The results highlighted that on the one hand, the addition of microcapsules increased the porosity, resulting in a reduced compressive strength for both concrete and geopolymer systems. On the other hand, a lower thermal conductivity and a higher thermal energy storage was achieved due to the addition of M-PCM in both systems. Commercially available M-PCM (paraffin) "powders", with a melting temperature of $23{ }^{\circ} \mathrm{C}$, were used by [6] in concrete mixtures for analyzing its thermal performances. This work remarked that the thermal efficiency of PCMs in building applications was limited due to the very low thermal conductivity of the PCM-concretes. Mechanical, fracture, and thermal tests were conducted by [78] on concrete made with powder M-PCMs (phase change temperature of $23 \pm 3^{\circ} \mathrm{C}$ ). This work highlighted the reduction in strength with increasing PCM dosages, however, this effect could be mitigated through the application of matrix strengthening, like, for example, silica fume additions. Contrarily, fracture properties, studied by various authors, were substantially less affected, especially for lower dosages of PCM. These results also highlighted the possibility to control thermal stresses in restrained concrete elements, whenever phase transitions occur during hydration at early-ages. The contribution in [79] deals with a new technique to measure the thermal conductivity and specific heat capacity of PCM-concrete bricks under phase change processes. Moreover, in [80], the thermal effect of micro-encapsulated PCMs mixed in concrete floors was investigated, while considering volumes that represented a scaled living space in dwellings. The behavior of self-compacting concrete containing micro-encapsulated PCMs was studied in [81]. This contribution also showed that with increasing amounts of PCM, a self-compacting PCM-concrete composite was obtained with a lower thermal conductivity and an increased heat storage capacity, both significantly contributing to the thermal performance and energy savings. As was also reported in other works, a significant loss in strength was observed whenever M-PCMs were added to a self-compacting concrete. A large number of M-PCM capsules were destroyed during the mixing process, as observed from a micro-structural analysis conducted by the authors [81]. The release of paraffin wax into the surrounding matrix was assumed to be responsible for the loss of strength. Real size concrete cubicles, for analyzing the improved thermal inertia as well as the inner thermal comfort, were investigated by [82] considering M-PCMs with a melting point of $26^{\circ} \mathrm{C}$. In recent years, additional mixing techniques have been proposed using expanded perlite particles [83]. These porous materials are capable of absorbing paraffin PCMs and can be used in direct mixing. It is remarkably that the initial principle of encapsulating waxes for novel thermal energy storage was developed for impregnating paraffin waxes into hydrophobically coated expanded perlite granules. In addition, binary mixtures consisting of capric, myristic, lauric, and palmitic acids were mixed as bio-based fatty acid PCMs in a solid form during concrete mixing by [84].

Macro-encapsulation deals with the integration of PCMs throughout "large" containers, such as tubes, spheres, panels, and/or other packages [31,41,52]. Among other works, macro encapsulated PCMs incorporated in concrete walls were discussed in [85]. In this regard, the effect of the position of macro-encapsulated PCM containers in concrete walls was evaluated, with special attention paid to the indoor temperature and humidity levels in the tested real size rooms. A thermal analysis of a concrete roof, having vertical cylindrical holes filled with PCMs, was realized and tested by [86]. Conventional and alveolar bricks with macro-encapsulated PCM were proposed by [87] as a Mediterranean construction under real conditions. The authors demonstrated a very good thermal behavior of these solutions in terms of energy savings and technical viability.

Aggregate impregnation is on PCMs embedded in porous aggregates. Thermal energy storage aggregate (TESA), e.g., natural, lightweights or recycled ones, is another possible technique to produce concrete and/or mortars with PCMs $[88,89]$. Thermo-physical properties and the mechanical behavior of cement-based mortars with PCMs incorporated in light weight aggregates (LWAs) were investigated 
by [90]. In this campaign, different dosages of paraffin waxes were included by immersion and by employing two alternative procedures to dry the LWA surfaces, i.e., compressed air or oven dried. The output of this work showed that high thermal inertia can be obtained whenever mortars are used that have LWAs filled with PCMs. In addition, it turned out that the thermal energy response could be enhanced when the PCM in LWA were filled up to a certain degree of its volume fraction. After that, the response could decrease. Fine lightweight aggregates with four different kinds of PCMs were used in PCM-mortars while aiming to reduce the freeze/thaw damage induced by various temperature cycles [91]. In this study, the PCMs were embedded in the aggregates by capillary suction during $24 \mathrm{~h}$ and at a constant temperature of $40{ }^{\circ} \mathrm{C}$. The compressive strength, isothermal calorimetry, and thermal property were also analyzed. Experimental studies focusing on the benefits of LWAs used as internal reservoirs to store PCMs, for higher and lower temperature PCMs and for different freeze/thaw cycles, were performed by [92]. TESAs in concrete were also investigated by [89]. Image analysis and mercury porosimetry helped to understand the efficiency of these systems, as aggregates with a large pore connectivity and transport ability can absorb more PCMs. Particularly, it turned out that the inner geometry of the aggregates' porous structure may have a significant effect on their ability to absorb PCMs.

\section{Phase Change Materials: Stefan Problem}

Phase change materials for building applications are characterized by solidification or melting when phase transitions take place, i.e., from liquid to solid or vice versa. In this particular situation, a heat-conduction problem according to the so-called Stefan problem can be applied.

The Stefan problem assumes the existence of two different domains, one representing the solid region $\left(\Omega_{\mathrm{S}}\right)$ and another representing the liquid $\left(\Omega_{\mathrm{L}}\right)$. The aforementioned domains are thus separated by a sharp surface front, namely a moving interface $(\Gamma)$. Such a sharp surface front is characterized by a temperature field that equals the melting temperature, $T_{m}$ (Figure 1).

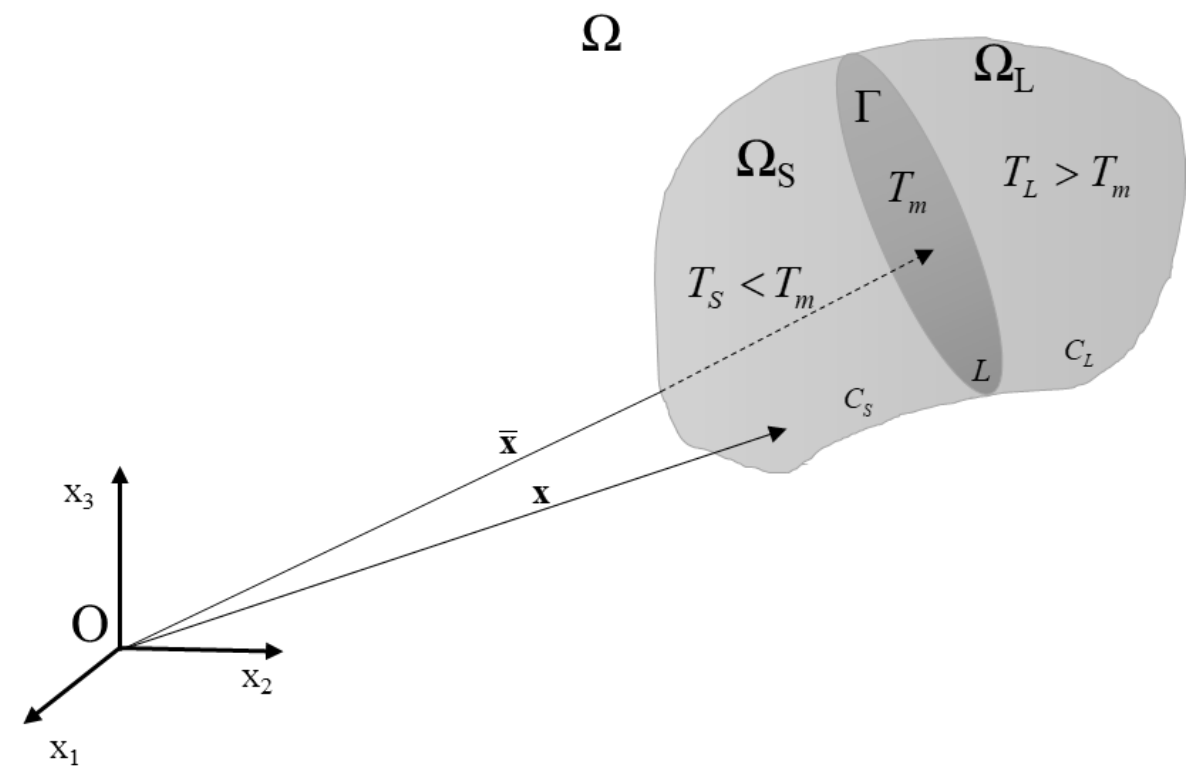

Figure 1. Schematic view of the Stefan problem.

The governing equations of the PCM heat conduction problem, under both solid-liquid (melting) and/or liquid-solid (solidification) transitions can be summarized as follows. Assumptions of the physical problem follow the classical approach of the Stefan problem, and considers it only as a conduction-based problem, a constant latent heat capacity $(L)$, a fixed melting temperature for PCM $\left(T_{m}\right)$, a zero-thickness interface of the sharp surface front (i.e., no mushy transition zone is considered), 
and the absence of nucleation and supercooling phenomena. According to these assumptions, the mathematical model can be formulated as follows.

Heat transfer problem in the solid (S) part:

$$
\rho C_{S} \frac{\partial T_{S}}{\partial t}=\nabla \cdot\left(\lambda_{S} \nabla T_{S}\right)+\dot{q}_{v, S} \forall \mathbf{x} \in \Omega_{\mathbf{S}}
$$

Heat transfer problem in the liquid (L) part:

$$
\rho C_{L} \frac{\partial T_{L}}{\partial t}=\nabla \cdot\left(\lambda_{L} \nabla T_{L}\right)+\dot{q}_{v, L} \forall \mathbf{x} \in \Omega_{\mathbf{L}}
$$

Heat balance at the sharp front interface (namely the Stefan condition):

$$
\lambda_{S} \nabla T_{S} \cdot \mathbf{n}-\lambda_{L} \nabla T_{L} \cdot \mathbf{n}=\rho L \frac{d \overline{\mathbf{x}}}{d t} \cdot \mathbf{n} \forall \overline{\mathbf{x}} \in \Gamma
$$

with $\rho$ as the density (considered constant when limited temperature variations occur, as is the case for PCM thermal problems, or, more generally, the density may depend on the position, $\mathbf{X}$, and temperature field $), \lambda_{S}=\lambda_{S}\left(T_{S}, \mathbf{x}\right)$ and $\lambda_{L}=\lambda_{L}\left(T_{L}, \mathbf{x}\right)$ are the solid and liquid thermal conductivities, $C_{S}=C_{S}\left(T_{S}, \mathbf{x}\right)$ and $C_{L}=C_{L}\left(T_{L}, \mathbf{x}\right)$ are the heat capacities, $T_{S}$ and $T_{L}$ are the temperatures of the solid and liquid parts, while $\dot{q}_{v, S}$ and $\dot{q}_{v, L}$ are the source terms. Additionally, $t$ represents the time variable, while $\nabla$ and $\nabla$ are the divergence and gradient tensorial operators, respectively. In Equation (3), $\mathbf{n}=\mathbf{n}(\overline{\mathbf{x}})$ is the unit normal vector on the moving interface, $\frac{d \overline{\mathbf{x}}}{d t}$ is the velocity of the interface, and $L$ is the latent heat per unit mass.

Several authors have proposed analytical solutions for the above model, under the assumption of a simplified mono-dimensional situation for the heat conduction in the solid and liquid phases [93,94]. These proposals deal with simplified solutions for a one-dimensional model to determine the solid and liquid temperature field analytically as well as the solid-liquid interface during the solidification/melting processes (see a.o. the following works [95-100]).

More complex models can be handled by neglecting the aforementioned simplifications as were done in the original Stefan problem. In many solutions, the mushy zone (part of the materials' interface in which the liquid and solid phases both may coexist) is not considered. Available proposals in the literature accounted for an explicit consideration of the mushy region. A computational fluid dynamics model was proposed by [101] for analysis of the phase change materials in building applications that consider three phase states, viz. mushy, solid, and liquid. The enthalpy approach outlined by $[102,103]$ showed the ability to consider the possible occurrence of PCM mushy zones. These proposals were conceived in the general framework of convection/diffusion problems and showed compatibility such that they could be accounted for in fluid flow software. The same procedure, also known in the literature as the enthalpy-porosity approach, was followed recently by [104] for transient numerical simulations of melting/solidification processes of sodium nitrate $\left(\mathrm{NaNO}_{3}\right)$, used as a phase change material. In addition, the effect of internal air void formation in encapsulated PCMs were investigated by [105]. In this proposal, a combination of the volume to fluid method, following the enthalpy-porosity approach, were conducted to schematize all phases present in a capsule: i.e., solid, liquid, mushy part, and air.

Several authors pointed out the importance to also consider the conduction processes jointly with natural convection (mainly interesting for the motion of the liquid phases), which could significantly affect the phase change process. In this case, the governing equations for the convection-condition as a transient analysis of a melting process of PCMs follow the so-called Navier-Stokes equation, continuing equilibrium, and the energy equation [106,107]. However, it may be worth mentioning that if a thermal system contains a small fraction of PCMs (as is the case for cementitious composites with PCMs), only the conduction mode can be considered, which avoids the complexity of modeling the natural convection flow in the mushy and liquid phases [108-110]. 
The numerical tools needed for addressing the solution of the Stefan problem (and/or its extended formulations) can generally be subdivided into the following three different types:

- Fixed grid method: In this approach, a grid of spatial nodes used for discretizing the problem remains fixed during time, while the problem is studied with auxiliary constitutive formulations and state functions, which help to trace the phase change phenomena governed by solidification and/or melting. These models are mostly employed and several examples can be found in the scientific literature. Pioneer contributions in this fixed grid method can be found in [94,111-113].

- Deformed grid method: In this approach, the nodes forming the grid may move to follow the sharp fronts and interfaces occurring during melting and solidification. These models are thus able to solve the Stefan problem and to follow, by deforming the grid, i.e., the Stefan condition, as the solution evolves [114,115].

- Hybrid fixed/deformed method: These approaches couple solutions from discretized partial differential equations solved in a "ghost" fixed grid, with local front tracking schemes, which are based on deformed grid procedures $[94,97,116]$.

The following section presents an overview of a fixed grid method, highlighting the governing equations and numerical solutions, and emphasizes the difference between them.

\section{Fixed Grid Numerical Method}

As already mentioned above, the fixed grid method is the simplest method to solve thermal problems involving phase changes. The basic equation of a heat conduction problem (the discussion is limited to conduction problems only, as they are applicable for cement-based composites in building physics problems) can be written as follows:

$$
\frac{\partial H}{\partial t}=\nabla \cdot(\lambda \nabla T)+\dot{q}_{v} \forall \mathbf{x} \in \Omega
$$

where $H$ is the enthalpy of the system, $\lambda=\lambda(T, \mathbf{x})$ is the thermal conductivity of the material, depending on the temperature, $T$, and position, $\mathbf{X}$, and the heat capacities, while $\dot{q}_{v}$ is the source term.

The initial and boundary condition to solve Equation (4) are the following:

$$
\begin{array}{cl}
T(\mathbf{x}, t=0)=T_{0}(\mathbf{x}) & \forall \mathbf{x} \in \Omega \\
T(\mathbf{x}, t)=T_{D} & \forall \mathbf{x} \in \Gamma_{T} \\
(\lambda \nabla T) \cdot \mathbf{n}=q & \forall \mathbf{x} \in \Gamma_{q} \\
(\lambda \nabla T) \cdot \mathbf{n}=h\left(T_{\infty}-T\right) & \forall \mathbf{x} \in \Gamma_{c}
\end{array}
$$

$\Gamma_{T}, \Gamma_{q}$ and $\Gamma_{c}$ are the boundaries of the domain $\Omega$, where the essential (Dirichlet) and natural boundary conditions are imposed; $T_{D}$ is the specified temperature; $q$ is the flux; $h$ is the heat convection coefficient; and $T_{\infty}$ is the environmental temperature.

When the domain splits in two or three phases (i.e., liquid, solid, mushy), additional boundary conditions (Stefan conditions) need also to be considered. Particularly, in the case of an isothermal phase change, these additional conditions are represented by Equation (3) plus the following one:

$$
T_{S}(\mathbf{x}=\overline{\mathbf{x}})=T_{L}(\mathbf{x}=\overline{\mathbf{x}})=T_{m} \forall \overline{\mathbf{x}} \in \Gamma
$$

and analogously, in the case of a non-isothermal phase-change, which deals with the presence of a so-called mushy range, the Stefan conditions must be imposed, and can be extended to account for a third phase (mushy), where the heat balance is then imposed at two sharp front interfaces, i.e., a mushy-liquid surface and a mushy-solid one.

In the framework of the fixed grid method, several proposals can be found in the literature, always starting from Equation (4). From this, a distinction can be made mainly in three families: i.e., 
(i) the enthalpy-based method (EM), (ii) the apparent calorific capacity method (ACCM), and (iii) the heat source method (HSM). All these (sub-)methods are capable of determining a posteriori the moving front of melting or solidification. The following subsections describe a flavor of each of these approaches and highlight the available numerical techniques necessary for their solution.

\subsection{Enthalpy-Based Method}

The enthalpy-based method (EM), which solves a diffusion phase change problem in a general way, is based on a direct solution of the system of Equations (4)-(7).

In a general sense, the enthalpy of a system, $H$, in Equation (4) can defined as follows:

$$
H(T)=\int_{T_{r e f}}^{T} \rho C(T) d T
$$

where $\rho C(T)$ is the volumetric heat capacity and $T_{\text {ref }}$ is a reference temperature.

In the case of a PCM, Equation (8) modifies into:

(i) PCM with an isothermal phase change:

$$
H(T)= \begin{cases}\int_{T_{r e f}}^{T} \rho C_{S}(T) d T & \text { when } T \leq T_{m} \text { (solid phase) } \\ \int_{T_{r e f}}^{T_{m}} \rho C_{S}(T) d T+\rho L+\int_{T_{m}}^{T} \rho C_{L}(T) d T & \text { when } T>T_{m} \text { (liquid phase) }\end{cases}
$$

(ii) PCM with an non-isothermal phase change (presence of a mushy zone):

$$
H(T)= \begin{cases}\int_{T_{\text {ref }}}^{T} \rho C_{S}(T) d T & \text { when } T \leq T_{\text {sol }} \text { (solid phase) } \\ \int_{T_{\text {rof }}}^{T_{\text {ref }}} \rho C_{S}(T) d T+\rho L f(T) & \text { when } T_{\text {sol }}<T \leq T_{\text {liq }} \text { (Mushy phase) } \\ \int_{T_{\text {ref }}}^{T_{\text {sol }}} \rho C_{S}(T) d T+\rho L+\int_{T_{m}}^{T} \rho C_{L}(T) d T & \text { when } T>T_{\text {liq }} \text { (liquid phase) }\end{cases}
$$

where $T_{\text {sol }}$ and $T_{\text {liq }}$ are the solid-mushy and mushy-liquid temperatures, respectively, while $\rho C_{S}(T)$ and $\rho C_{L}(T)$ are the volumetric heat capacity for the solid and liquid phases, respectively. The function, $f(T)$, in the mushy region is equal to 0 when $T=T_{\text {sol }}$ and 1 when $T=T_{\text {liq }}$, allowing the definition of $L$ (latent energy heat per unit mass), which represents the energy for a unit volume of solid to be completely transformed into a liquid.

In the case of constant heat capacities and linear expressions of the $f(T)$ function, Equations (9) and (10) reduces into:

(i) PCM with an isothermal phase change (Figure 2a):

$$
H(T)= \begin{cases}\rho C_{S} T & \text { when } T \leq T_{m} \text { (solid phase) } \\ \rho\left(C_{S} T_{m}+L+C_{L}\left(T-T_{m}\right)\right) & \text { when } T>T_{m} \text { (liquid phase) }\end{cases}
$$

(ii) PCM with a non-isothermal phase change (presence of a mushy zone, see Figure 2b): 


$$
H(T)= \begin{cases}\rho C_{S} T & \text { when } T \leq T_{\text {sol }} \text { (solid phase) } \\ \rho\left(C_{S} T_{\text {sol }}+L \frac{T-T_{\text {sol }}}{\left.T_{\text {liq }}-T_{\text {sol }}\right)}\right. & \text { when } T_{\text {sol }}<T \leq T_{\text {liq }} \text { (Mushy phase) } \\ \rho\left(C_{S} T_{\text {sol }}+L+C_{L}\left(T-T_{\text {liq }}\right)\right) & \text { when } T>T_{\text {liq }} \text { (liquid phase) }\end{cases}
$$

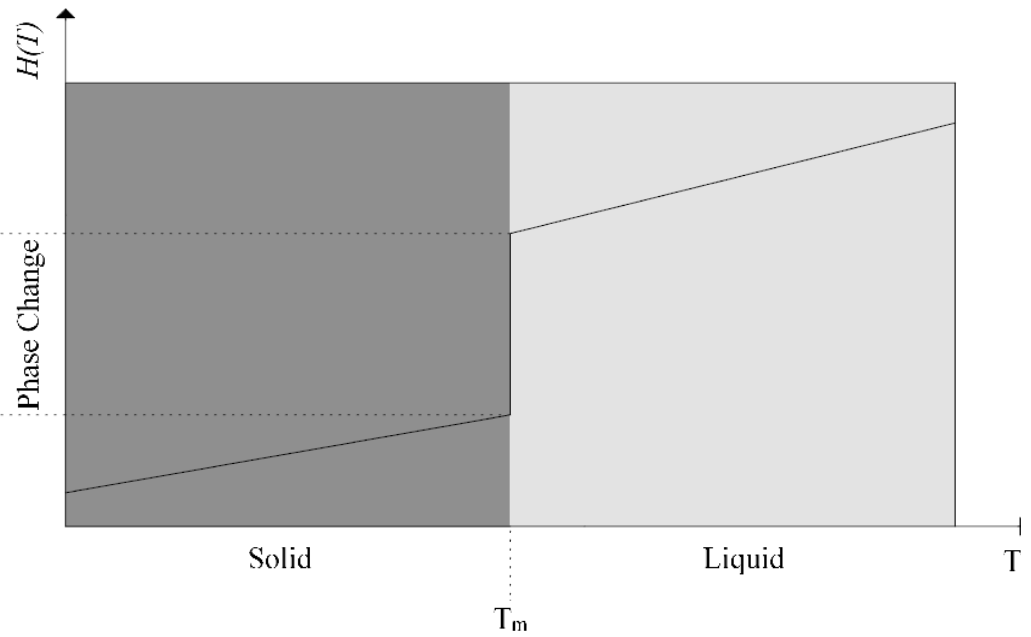

(a)

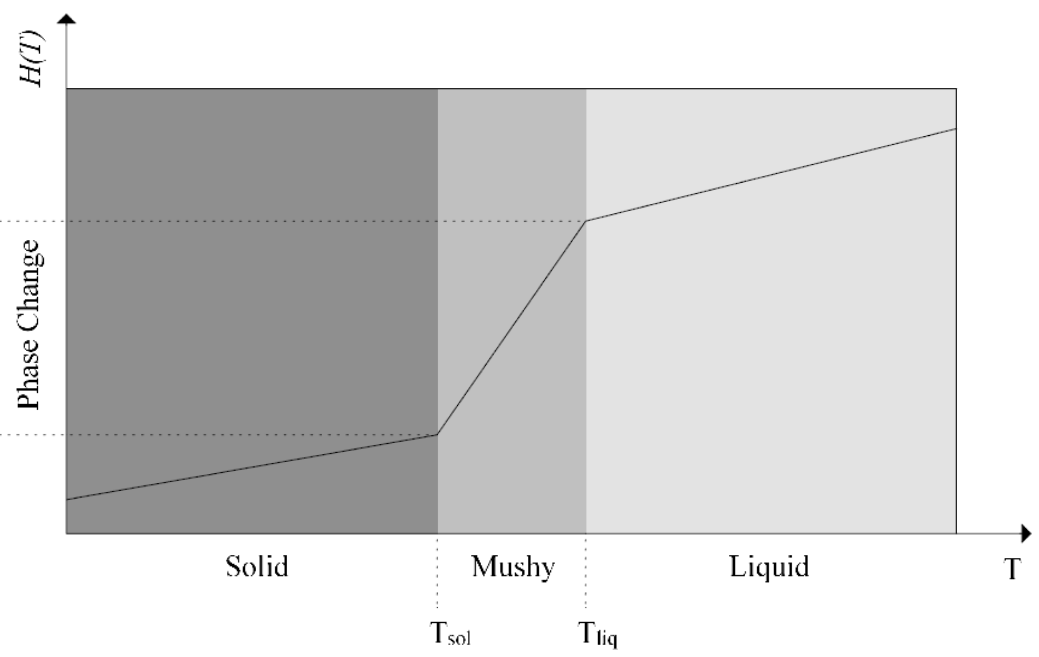

(b)

Figure 2. H-T behavior with constant heat capacities and using linear expressions of the $f(T)$ function: (a) Iso-thermal and (b) non-isothermal phase change.

This approach is commonly employed for solving diffusion phase change problems, and was proposed for the first time by Eyres et al. [111]. An implicit enthalpy scheme for a one-dimensional phase change problem applied to the solution of a binary alloy solidification problem was discussed by Voller [117]. The author mainly proposed a method to solve a one dimensional (1D) problem with an isothermal phase change as outlined in Equations (9) and (11). After that, the model was extended to solve convection/diffusion phase change problems and was developed and described by Voller et al. [103,118]. A detailed discussion on the enthalpy method and its derivation of the apparent heat capacity as well as the source based method was given in [119]. In the framework of the enthalpy method, a finite element based formulation for solving coupled nonlinear heat conduction/diffusion processes, including phase changes, was developed by [120]. In addition, a fully implicit finite 
difference method was proposed by Costa et al. [121]. The method was validated for conduction plus convection under $1 \mathrm{D}$ conditions, while for a two-dimensional case, the same calculations were performed for a conduction case study only. Simple unidimensional computational conduction models for isothermal PCM, enclosed in single rectangular and cylindrical containers, were highlighted in [122]. Using the Galerkin finite element method, Bhattacharya et al. [123] solved phase change problems for pure and multicomponent phases, using the enthalpy method and paying special attention to the role of the mushy region. A Newton-type of iterative procedure was proposed by Nedjar [124] to solve stationary and transient problems in the field of both classical finite difference schemes and finite element procedures. Commercial paraffin waxes, stored in vertical and rectangular containers, were simulated with a 1D enthalpy-based model [125], employed for modelling a wall subjected to a constant heating-rate acting from one side, with an airflow stream on the other side. The enthalpy method was also used for solving the so-called Stefan problem through a Neumann-type boundary condition and a finite difference approximation by [126]. The difference between the enthalpy method and the effective heat capacity approach was outlined by Lamberg et al., who obtained several validations of the numerical tools using the commercial Femlab/Comsol program [127]. A slightly modified version of the enthalpy method was then proposed by Vyshak and Jilani [128]. In this proposal, the temperature was decoupled from the liquid fraction field, where this latter was updated, explicitly, through the currently known temperature field.

For building applications with PCM, the enthalpy method has been employed in a few examples. It can be mentioned that the study of Izquierdo-Barrientos et al. [129] deals explicitly with the transient heat transfer through different walls/layers. The authors developed a 1D transient conduction model for typical winter/summer temperature fluctuations. The commercially available computational fluid dynamics code FLUENT, which is based on the enthalpy method, was employed by $[130,131]$ to conduct numerical studies for the thermal performance of building walls and roofs with PCMs for residential applications. Finally, recently, an interesting numerical study based on the enthalpy method was employed in the medicine field by Kumar et al. [132]. Particularly, this work reported a numerical investigation of a phase change heat transfer process in a lung undergoing cryosurgery.

\subsection{Apparent Calorific Capacity Method (ACCM)}

The apparent calorific capacity method (ACCM) considers the effect of enthalpy and its evolution in time by considering an apparent (or sometime called effective) heat capacity during thermal phase changes.

The approach is based on the following relationship:

$$
\frac{\partial H}{\partial t}=\frac{\partial H}{\partial T} \frac{\partial T}{\partial t}
$$

where $\frac{\partial H}{\partial T}=\rho C_{e f f}(T)$ represents the temperature-dependent apparent (effective) heat capacity [133].

According to this, Equation (4) modifies into the classical heat equation as follows:

$$
\rho C_{e f f}(T) \frac{d T}{d t}=\nabla \cdot(\lambda \nabla T)+\dot{q}_{v} \forall \mathbf{x} \in \Omega
$$

The method has been well used in the literature since, in this approach, the temperature is the only variable that needs to be solved, discretized, and simulated. Actually, Equation (14) shows a problem that mainly deals with a classical heat problem. The key novelty of this method is to achieve a proper representation of the apparent capacity, $C_{\text {eff. }}$. Table 2 outlines various proposals for describing the apparent calorific capacity for a phase change process as available in the scientific literature. 
Table 2. ACCM-based proposals in the framework of fixed grid methods.

\begin{tabular}{|c|c|}
\hline Authors & Apparent Heat Capacity- $C_{e f f}$ \\
\hline $\begin{array}{c}\text { Lamberg et al. (2004) [127] } \\
\text { Bonacina et al. (1973) [134] } \\
\text { Idelsohn et al. (1994) [135] } \\
\text { Voller (1997) [136] } \\
\text { Pasupathy et al. (2008) [137,138] } \\
\text { Zang et al. (2008) [139] } \\
\text { Fang and Medina (2009) [140] } \\
\text { Thiele et al. (2015) [141] } \\
\text { Šavija and Schlangen (2016) [142] }\end{array}$ & $C_{e f f}= \begin{cases}C_{S} & T \leq T_{m}-\Delta T \\
\frac{L}{2 \Delta T}+\frac{C_{S}+C_{L}}{2} & T_{m}-\Delta T<T \leq T_{m}+\Delta T \\
C_{L} & T>T_{m}+\Delta T\end{cases}$ \\
\hline Hu and Argyropoulos (1996) [143] & $C_{e f f}=\left\{\begin{array}{llc}C_{S} & T \leq T_{\text {sol }} & \int_{\text {liq }} \\
C_{\text {in }} & T_{\text {sol }}<T \leq T_{\text {liq }} & C_{\text {in }}=\frac{\int_{T_{\text {sol }}}}{\left(T_{\text {liq }}-T_{\text {sol }}\right)} \\
C_{L} & T>T_{\text {liq }}\end{array}\right.$ \\
\hline $\begin{array}{c}\text { Samarskii and Vabishchevivh (1995) [144] } \\
\text { Heim and Clarke (2004) [145] } \\
\text { Heim (2010) [146] }\end{array}$ & $\frac{\partial H(T)}{\partial t}=\rho C_{e f f}(T) \frac{\partial T}{\partial v} \frac{\partial v}{\partial t} \quad v=\int_{C_{s o l}}^{C_{l i q}} C_{e f f}(T) d T$ \\
\hline $\begin{array}{c}\text { Zukowski (2007) [147] } \\
\text { Mankel et al. (2019) [148] }\end{array}$ & $\begin{array}{c}C_{e f f}=C_{p, \mathrm{P}}=f\left(T_{\mathrm{P}}\right) \\
\text { tabular data and interpolated with cubic spline function method } \\
\text { tabular data from DSC tests }\end{array}$ \\
\hline Evola et al. (2013) [149] & $\begin{array}{l}C_{e f f}= \begin{cases}1200+18800 \cdot e^{-\left(\frac{T p-T}{1.5}\right)} & T \leq T_{p} \\
1300+18700 \cdot e^{-4(T p-T)^{2}} & T>T_{p}\end{cases} \\
\text { equivalent heat capacity of PCM wallboards }\end{array}$ \\
\hline $\begin{array}{l}\text { Thiele et al. (2015) [141,150] } \\
\text { (for composite applications: i.e., } \\
\text { cementitious ones) }\end{array}$ & $\begin{array}{l}(\rho C)_{e f f}(T)= \begin{cases}(\rho C)_{e f f, S} & T \leq T_{m}-\Delta T \\
(\rho C)_{e f f, S}+\phi_{c} \frac{L}{2 \Delta T} & T_{m}-\Delta T<T \leq T_{m}+\Delta T \\
(\rho C)_{e f f, L} & T>T_{m}+\Delta T\end{cases} \\
(\rho C)_{e f f, S}=\begin{array}{c}\phi_{c}(\rho C)_{c, S}+\phi_{s}(\rho C)_{s}+\left(1-\phi_{c}-\phi_{S}\right)(\rho C)_{m} \\
\text { concrete matrix }\end{array} \\
\text { composite core of the MPCM shell of the MPCM } \\
\phi_{c} \text { volume fraction of MPCM core } \\
\phi_{s} \text { volume fraction of MPCM shell } \\
\phi_{m} \text { volume fraction of concrete matrix } \\
\quad(\rho C)_{e f f, L}=(\rho C)_{e f f, S}+\phi_{s}+\phi_{m}=1\end{array}$ \\
\hline $\begin{array}{c}\text { Tittelein et al. (2015) [151] } \\
\text { Kheradmand et al. (2016) [152] } \\
\text { (for composite applications: i.e., } \\
\text { cementitious ones) }\end{array}$ & $\begin{array}{cl}C_{e f f}=X_{\text {mort }} \cdot C_{\text {mort }}+X_{P C M} \cdot C_{P C M} & C_{\text {mort }}=\text { constant } \\
\text { being } X_{\text {mort }} \text { and } X_{P C M} \text { mass fractions } & C_{P C M}=f(T)\end{array}$ \\
\hline Yao et al. (2018) [153] & $\begin{array}{c}C_{e f f}= \begin{cases}\frac{C_{S}+C_{L}}{2} & T \leq T_{m}-\Delta T_{1} \\
\frac{L}{2 \Delta T_{1}}+\frac{C_{S}+C_{L}}{2} & T_{m}-\Delta T_{1}<T \leq T_{m}+\Delta T_{1} \quad \text { melting } \\
\frac{C_{S}+C_{L}}{2} & T>T_{m}+\Delta T_{1}\end{cases} \\
C_{e f f}= \begin{cases}\frac{C_{S}+C_{L}}{2} & T \leq T_{S}-\Delta T_{2} \\
-\frac{L_{2}}{2 \Delta T_{2}}+\frac{C_{S}+C_{L}}{2} & T_{S}-\Delta T_{2}<T \leq T_{S}+\Delta T_{2} \quad \text { solidification } \\
\frac{C_{S}+C_{L}}{2} & T>T_{S}+\Delta T_{2}\end{cases} \end{array}$ \\
\hline Young et al. (2018) [154] & $\begin{array}{l}\frac{(\rho C)_{e f f}(T)}{(\rho C)_{e f f, s}}= \begin{cases}1 & T \leq T_{m}-\frac{\Delta T}{2} \\
1+\phi_{c+s} \frac{L^{*}}{\Delta T} & T_{m}-\frac{\Delta T}{2}<T \leq T_{m}+\frac{\Delta T}{2} \\
1 & T>T_{m}+\frac{\Delta T}{2}\end{cases} \\
L^{*}=\text { dimensionless latent heat of fusion }\end{array}$ \\
\hline Singh and Bhat (2018) [155] & $C_{e f f}= \begin{cases}C_{S}+C_{p, \max } \cdot e^{\left(\frac{\left(T_{m}-T\right)^{2}}{2 W^{2}}\right)} & T \leq T_{m} \\
C_{L}+C_{p, \max } \cdot e^{\left(\frac{\left(T_{m}-T\right)^{2}}{2 W^{2}}\right)} & T>T_{m}\end{cases}$ \\
\hline Han et al. (2018) [156] & $\begin{array}{l}(\rho C)_{e f f}=\phi_{p h 1}(T) \rho_{p h 1} C_{p h 1}+\left(1-\phi_{p h 2}(T)\right) \rho_{p h 2} C_{p h 2}+\underset{\text { phase } 2}{\rho L \frac{\partial \alpha_{m}}{\partial T}} \\
\begin{array}{l}\text { latent part } \\
\text { composite }\end{array} \\
\alpha_{m}=\text { smooth transition function }\end{array}$ \\
\hline
\end{tabular}




\subsection{Heat Source Method (HSM)}

The heat source method (HSM) separates the enthalpy into two parts, viz. a sensible and a latent one. The latent term is thus used as a source term in the classical heat equation as follows:

$$
\frac{\partial H}{\partial t}=\frac{\partial H}{\partial T} \frac{\partial T}{\partial t}=\left[\rho C(T)+\rho L \frac{\partial f(T)}{\partial T}\right] \frac{\partial T}{\partial t}
$$

Combining Equations (4) and (15), the following heat equation can be obtained:

$$
\rho C(T) \frac{d T}{d t}=\nabla \cdot(\lambda \nabla T)+\dot{q}_{v}-\rho L \frac{d f(T)}{d t} \forall \mathbf{x} \in \Omega
$$

where $-\rho L \frac{d f(T)}{d t}=S$ represents the so-called source term due to the latent part of the enthalpy.

This method was originally proposed by Eyres et al. [111] based on the idea that heat enthalpy, $H$, is function of the temperature and volume fraction of the material that is affected by the phase change process. According to this hypothesis, the author reached an expression similar to Equations (15) and (16), envisioning the pioneering contribution of this proposal. An alternative proposal was developed by Voller (1995) [157], where, based on an implicit finite-difference discretization, the enthalpy formulation was separated into a sensible and latent heat term. The resulting set of non-linear equations was based on isolation of the source latent term while the method offered the advantage that only the temperature field needs to be solved in the resulting iterative heat equation scheme. Following this proposal, a new coupled HSM-based scheme was developed by Swaminathan and Voller (1997) [158] aimed at simulating the solidification behavior of multicomponent alloys for a wide range of local scale behaviors. Latent heat storage systems were also designed by Costa et al. (1998) [121], using an enthalpy formation solved through a fully implicit finite difference method and the HSM. The proposal of these authors deals with a non-linear system of equations with the only isolated variable being the enthalpy (so, not the temperature as usually adopted in these thermal-based problems). The solution of a temperature-based transient heat conduction problem involving phase changes was solved by Fachinotti et al. (1999) [159] in the framework of a finite element model and using the HSM approach. Brusche et al. (2006) [160] used the HSM for modelling phase-change layers in optical rewritable recordable media, while prior to that, a mathematical model was developed by Rostamizadeh et al. (2012) [161], showing an enthalpy formulation with the HSM technique and the effect of PCM thickness in energy storage systems. All the discussed proposals are summarized in Table 3.

Table 3. HSC proposals in the framework of fixed grid methods.

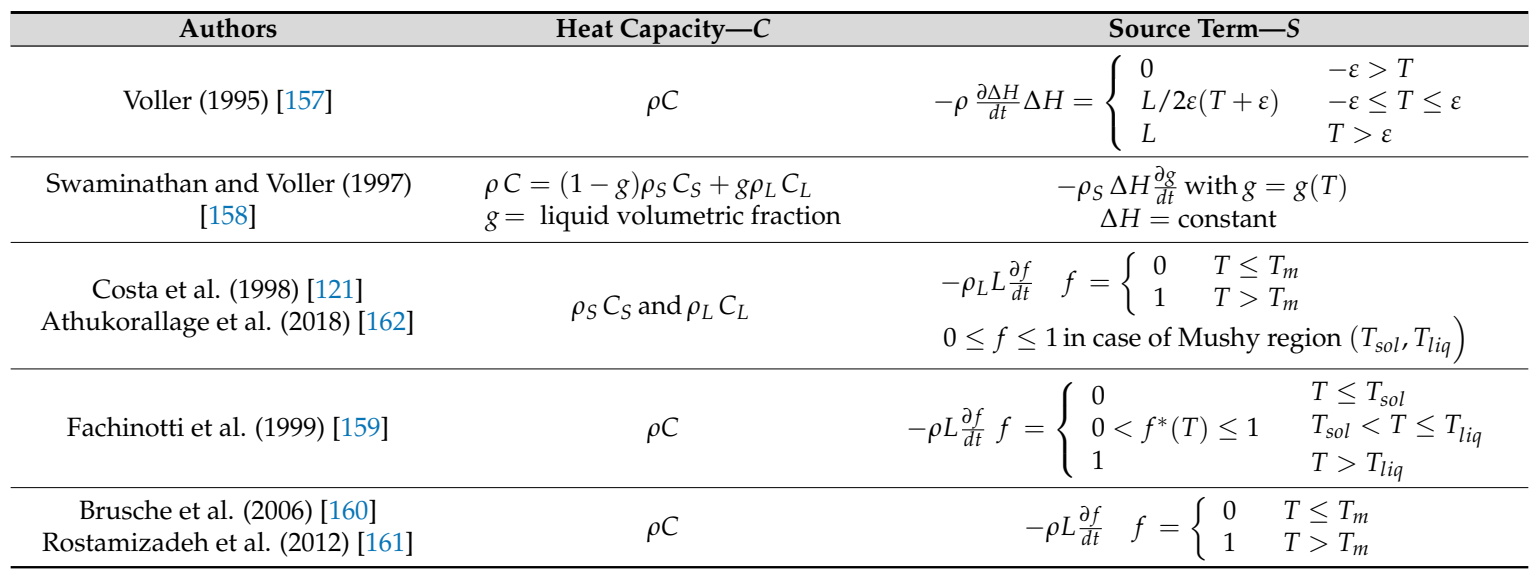




\subsection{Concluding Remarks on Fixed Grid Method}

The above described methods are employed to simulate phase change processes governed by solidification and melting phenomena. As outlined before, in the enthalpy method (EM), the enthalpy variable is the decisive parameter that accounts for separating the sensible and latent heat parts for both isothermal phase changes and for those cases where mushy regions are present. Contrarily, the apparent calorific capacity method (ACCM) is a simpler method where the sensible and latent heat energy parts are lumped. Finally, the heat source method (HSM) treats the latent heat as a source term to obtain a temperature-based differential equation to be solved.

The EM and HSM are the only choices to be followed in the case of isothermal phase changes and/or for those cases where a phase change occurs in a small temperature range. On the other hand, ACCM is very easy to program being quite similar to the classical heat (conduction) problem with the only difference that the heat capacity is now temperature-dependent. ACCM is suitable for gradual phase changes, while it is not useful for isothermal phase changes (a jump in the $\mathrm{H}-\mathrm{T}$ curve cannot be well captured by an appropriate description of $C_{e f f}$ ).

In the framework of a finite element procedure, the preferred methods to be used are the ACCM and the HSM, due to the fact that the only dependent variable is temperature, which characterizes the problem. Even though, since the HSM can be employed for gradual, sharp, and isothermal phase processes, this method is the best choice for FE simulations and PCM analysis.

\section{Cementitious Porous Materials with PCM: Numerical Models and Scales}

Nowadays, many theoretical and numerical models are available for simulating heat storage phenomena in porous composites, like concrete, mortar, gypsum, etc. This section reports the available models developed in the last two decades and categorizes them by means of the different scales of observation.

Concrete and other cementitious materials are multiphase (composite) materials. For this reason, it can be considered and modelled as a homogeneous continuum at the macroscale and even structural scale, while at lower levels (meso-, micro-, and nano-scales), it can be considered as an inhomogeneous multiphase material.

\subsection{Structural-Scale Models}

These models allow capturing of the essence of heat storage phenomena at the structural (building physics) scale level. The major objective of these formulations is to build up simplified methods, sometime practice-oriented, for predicting the temperature fluctuations and thermal comfort in certain construction.

Numerical tools for analyzing multi-zone solar buildings, having PCM-impregnated gypsum plasterboard, were proposed by Heim et al. $[145,146,163]$. These authors used the commercial ESP- $r$ program (numerical code for building physics performance simulation) to incorporate the effects of phase change materials. Further case studies concerning whole building thermal performances dealing with wallboards containing PCMs and micro-encapsulated PCMs in thin wallboards were investigated by Evola et al. in [149] and [164], respectively.

Moreover, building physics simulations using available commercial codes for PCMs in building applications are those related to the use of TRNSYS (Transient System Simulation Tool) [165-167], the International Building Physics Toolbox (libraries and models for Matlab/Simulink) [168-171], and other commercial programs, such as EnergyPlus, RadCool (a Web-enabled Simulation Tool for Radiative Cooling), CoDyBa, BSim, PCM Express and Wufi [172].

\subsection{Macro-Scale Models}

In the field of computational mechanics, macro-scale models for analyzing heat transfer phenomena in cement-based materials with PCMs are most popular and most frequently adopted. 
These models are based on the assumption that the schematized material acts as a continuum and homogenous medium. The most classical examples in this field are those related to the use of the aforementioned EM, ACCM, and HSM techniques [173] for macroscopic analysis of cementitious composites. Examples are from Pasupathy and Velraj $[137,138]$, who analyzed the thermal performance of building roofs with PCMs. The authors employed the ACCM in a macroscale model where the concrete slab, the roof top, and PCMs were considered as homogeneous and isotropic elements. To study the influence of a multi-layer wall, including PCMs, a macroscale transient heat transfer model was developed by [129]. In this study, the authors focused on the effects of different boundary conditions, wall configurations and orientations, ambient conditions, and phase transition temperatures of the PCM. Then, a macroscopic enthalpy-based model was analyzed by [174] with the aim to evaluate the related errors occurring when misinterpreted enthalpy functions are employed in thermal simulations. Furthermore, a four-layer roof containing PCM was approached macroscopically by [131] using EM in a Fluent software. In this respect, the recent works based on the fixed grid methods can be cited, i.e., Kong et el. [130], Tittelein et al. [151], and Kheradmand et al. [152].

A one-dimensional analytical model was proposed by Mirzaei and Haghighat [101], where the concept of resistances and capacitances with computational fluid dynamics ingredients were combined for analyzing multi-layer cementitious walls with PCMs. Similarly, a simplified dynamic model for concrete brick-walls with PCMs, based on the aforementioned resistances/capacitances, and combined with genetic algorithm-based procedures was developed by Zhu et al. $[175,176]$. In the field of finite element approaches, heat transfer processes of gypsum boards containing fatty acid PCMs was studied by [177] using the Ansys FEM code. Then, an FEM-based approach considering the ACCM was followed by Thiele et al. [150], who proposed a technique for estimating the specific heat capacity for a PCM-composite.

Several homogenization techniques were then proposed for estimating the macroscopic heat properties of cement-based composites. An interesting proposal was given by [178] who considered the PCM-composite to be homogeneous and isotropic, and outlined a homogenization technique that explicitly considered the superficial capsule area per unit mortar volume (expressed as a function of the volume fraction of PCM to the surrounding mortar and to the capsule diameter), employed for evaluating the composite thermal properties of the material. PCM-mortar composites were schematized as a homogeneous medium by [179], hence considering the average and isotropic properties. These authors proposed a mixed rule for accounting the mass enthalpy of a composite material (i.e., cement mortar plus the PCM). Furthermore, a macroscale model for simulating concrete slabs cast with microencapsulated PCMs was proposed by [180], where the thermo-physical properties of the PCM-concretes were estimated through an application of mixture theory, while an analytical expression was introduced for the effective apparent calorific capacity.

Some recent works also accounted for the estimation of PCM effects on the hydration process, and in particular on the mitigation of the reaction heat resulting as a partial reaction of the cement grains with water. A theoretical model of a heat-flow and hydration model for concrete hardening, including paraffin, was presented by Pei et al. [181]. Furthermore, a proposed model for early-age PCM-concretes by Arora et al. [182] demonstrated significant reductions in the peak hydration temperature when PCMs were considered as the partial replacement of the cement paste or fine aggregates. The authors also proposed a formulation that represents the hydration-dependency of the PCM thermal conductivity and heat capacity. A study to examine the benefits related to the addition of microencapsulated PCMs in concrete pavement sections to mitigate the temperature rise during early-age cement hydration was recently proposed by Young et al. [183].

Equivalent thermal properties that can be used in the aforementioned macro-scale models and also the structural ones have been subject of research as well, with some works available in the literature. For example, a method based on a sequential quadric programming procedure to determine the specific calorific capacity and thermal conductivity of PCM-concrete bricks was proposed by [79]. A general discussion with many examples was done by Felske [184], addressing an evaluation 
of the effective thermal conductivity when composite spheres were merged in continuous media. The proposal by Felske [184] has been recently extended and verified by Thiele et al. [185] and Ricklefs et al. [186] for predicting the effective thermal conductivity of composite materials with PCM capsules. The Mori-Tanaka principles were then used by [187] for obtaining the macroscopic thermal conductivity of composites considering the effect of the interfacial particle resistance and their size distribution. The same approach was also followed by Stránsky et al. [188] to analyze the effective thermal conductivity of matrix-inclusion composites, and where some aspects were investigated, such as the orientation of particles and the perfect vs. imperfect interface. Furthermore, multi-step Mori-Tanaka homogenization techniques were employed by Aguayo et al. [189] to predict the thermal conductivity of the PCM-composites. Finally, a new hybrid technique was developed by Mandilara et al. [190] for estimating the effective heat capacity to be used in numerical simulations that account for PCM-concrete composites.

\subsection{Meso-Scale Models}

A better understanding of PCM mechanics subjected to external thermal fluctuations can be obtained by considering the mesoscale nature of the PCM composite materials. The mesoscale of concrete can be idealized by considering different phases, which together constitute such a composite. Thereby, the interaction among the different phases of the composite (i.e., matrix, coarse aggregates, PCMs, and interfaces between them) is explicitly considered in these approaches.

Only a few approaches are currently available in the literature for modeling meso-scale systems accounting for phase changes in concrete. In this field, a very simplified approach was proposed by Zhang et al. [139], where a 2D discretized model of a composite PCM-concrete was reported. The authors considered the PCM particles as circles with a radius of $1 \mathrm{~mm}$ and were uniformly distributed over the 2D geometry. No interface and thermal resistance were adopted. Furthermore, a heterogeneous meso-scale proposal based on a unit cell containing core-shell particles arranged in a periodic face-centered cubic packing was proposed by Thiele et al. [141]. This research was employed for validating a homogenization technique for continuous-based simulations compared with the same results obtained from a heterogeneous mesoscopic representation. Finite element simulations carried out on cementitious microstructures were proposed by Agauyo et al. [191] to investigate the influence of interface properties and PCM inclusions. The model explicitly considered the meso-scale with PCM cores and PCM shells of the micro-encapsulated PCM particles, the PCM-mortar interfaces, and the surrounding mortar matrix. A multi-scale model based on the analysis of a meso-scale RVE was also proposed by Mohaine et al. [192]. Particularly, the authors generated mesoscopic scale specimens based on a digital concrete model for generating random structures containing heterogeneities, like coarse aggregates and PCMs. The homogenization multiscale procedure, based on the finite element method, enabled the authors to obtain the thermo-mechanical parameters of cement paste and the concrete with PCMs. Furthermore, a two scale numerical model was proposed by Šavija and Schlangen [142], where at the meso-scale, the PCM microcapsules were explicitly simulated as embedded inclusions in the concrete matrix based on a discrete (lattice) model, while at the macro-scale, a commercial FE package was used to calculate the stress distributions from the PCM-affected temperatures in a wall-on-slab system. A meso-scale approach for determining the thermal deformation properties of microencapsulated PCMs embedded in cementitious composites was proposed by Young et al. [193], where various cell configurations with many different particle size distributions and packing arrangements were considered. Finally, the authors proposed a multiscale and thermodynamically consistency framework for solving thermo-mechanical problems with phase change phenomena [194].

\section{Concluding Remarks}

Accumulating solar and/or environmental heat in innovative materials for construction and building applications represents a way to level-out daily temperature differences and to significantly cut back on energy demands. A way to achieve this goal is to develop advanced cementitious 
composites that are characterized by a porous microstructure, which have the ability to accommodate phase change materials (PCMs) with the potential to store/relief energy during their phase changes from solid to liquid or vice versa.

From the current literature review, the following concluding remarks can be drawn:

- A large number of studies on various PCM-related topics are available in the literature. Some of them referring to specific topics from a material point of view (i.e., micro- and macro-encapsulation of PCM, thermal conductivity enhancements, thermal stability), while others refer to the possible field of application of PCMs, like thermal energy storages, high temperature applications, solar water heaters, cold applications, and building accumulation solutions;

- numerical solutions for analyzing the so-called Stefan problem in phase change materials were reviewed and discussed. The literature on different solution approaches was presented discussed;

- fixed grid method, representing the simplest approach for solving thermal problems involving PCMs, were reviewed and the basic equations behind this approach were outlined and discussed;

- in the framework of the fixed grid method, three different approaches were recognized, namely the "enthalpy-based method (EM)", the "apparent calorific capacity method (ACCM)", and the "heat source method (HSM)". All these methods have in common that they are capable of determining a posteriori the movement of the melting/solidification front according to the Stefan problem. The different methods and corresponding models associated with the EM, ACCM, and HSM approach were briefly described and discussed; and

- the available models for PCM-concrete composites, focusing on the different length scales, i.e., micro, meso, macro, and possible multiscale approaches, are being reviewed and discussed. Many articles on PCM-concretes followed a macroscopic and building scale approach, while only few contributions are available in the literature that deal with the meso- to micro-scale level.

As a final comment, it may be worth mentioning that although a significant research effort has already been contributed to the field of numerical modelling for heat transfer processes with PCM accumulations, further efforts in the field of cementitious composites embedding PCMs are certainly embraced. Unambiguous knowledge on how porous microstructures, like cementitious composites or aggregates, should be built up and/or what are the critical demands that allow empty pores to serve as "closed" encapsulation cavities is still lacking. A holistic approach, combining a micro- to mesoscale poro-analysis model with a multiscale/multiphysics approach, along with a microstructural response, moisture diffusivity, phase change, and thermal analysis, has not been published in the literature so far.

Recent developments on numerical modelling of composite systems, including micro- and mesoscale observations, for considering local effects, like, for example, pores, air bubbles, PCMs, aggregates, interfaces, etc., are currently ongoing at the WiB Institute of TU-Darmstadt. Advantages of these lower-scale simulations is that they allow optimization of the design of efficient PCM-cement systems, thus avoiding the performance of time-consuming experimental tests. On the other hand, multiscale modelling applications are also under development for simulating at several scales the energy storage capacity of PCM-concretes. There, a multiscale framework, consisting of coupled mechanisms with thermal/mechanical and phase transformation phenomena, was considered.

Author Contributions: The work presented in this review paper represents a collaborative development among all authors.

Funding: The APC was partially funded by the German Research Foundation (DFG) and the Open Access Publishing Fund of the Technische Universität Darmstadt.

Acknowledgments: The first author wishes to acknowledge the Alexander von Humboldt-Foundation (Germany, https: / / www.humboldt-foundation.de) for funding his position at the WiB - TU Darmstadt (https: / / www.wib. tu-darmstadt.de/) under the research Grant ITA-1185040-HFST-P (2CENERGY project). Also the support of the networking activities provided by the SUPERCONCRETE Project (H2020-MSCA-RISE-2014 n 645704), funded by the EU, is gratefully acknowledged. Finally, the authors acknowledge the German Research Foundation (DFG) and the Open Access Publishing Fund of the Technische Universität Darmstadt for partially funding the article processing charge (APC). 
Conflicts of Interest: The authors declare no conflict of interest.

\section{References}

1. Rezgui, Y.; Hopfe, C.J.; Vorakulpipat, C. Generations of knowledge management in the architecture, engineering and construction industry: An evolutionary perspective. Adv. Eng. Inform. 2010, 24, 219-228. [CrossRef]

2. Schneider, M.; Romer, M.; Tschudin, M.; Bolio, H. Sustainable cement production-present and future. Cem. Concr. Res. 2011, 41, 642-650. [CrossRef]

3. Miller, S.A.; Horvath, A.; Monteiro, P.J. Readily implementable techniques can cut annual $\mathrm{CO}_{2}$ emissions from the production of concrete by over 20\%. Environ. Res. Lett. 2016, 11, 074029. [CrossRef]

4. Pérez-Lombard, L.; Ortiz, J.; Pout, C. A review on buildings energy consumption information. Energy Build. 2008, 40, 394-398. [CrossRef]

5. Parameshwaran, R.; Kalaiselvam, S.; Harikrishnan, S.; Elayaperumal, A. Sustainable thermal energy storage technologies for buildings: A review. Renew. Sustain. Energy Rev. 2012, 16, 2394-2433. [CrossRef]

6. Pomianowski, M.; Heiselberg, P.; Jensen, R.L.; Cheng, R.; Zhang, Y. A new experimental method to determine specific heat capacity of inhomogeneous concrete material with incorporated microencapsulated-PCM. Cem. Concr. Res. 2014, 55, 22-34. [CrossRef]

7. Mehling, H.; Cabeza, L.F. Heat and Cold Storage with PCM an up to Date Introduction into Basics and Applications; Springer: Berlin, Germany, 2008.

8. Vélez, C.; Khayet, M.; de Zárate, J.O. Temperature-dependent thermal properties of solid/liquid phase change even-numbered n-alkanes: N-Hexadecane, n-octadecane and n-eicosane. Appl. Energy 2015, 143, 383-394. [CrossRef]

9. Pielichowska, K.; Pielichowski, K. Phase change materials for thermal energy storage. Prog. Mater. Sci. 2014, 65, 67-123. [CrossRef]

10. Iten, M.; Liu, S.; Shukla, A. A review on the air-PCM-TES application for free cooling and heating in the buildings. Renew. Sustain. Energy Rev. 2016, 61, 175-186. [CrossRef]

11. Souayfane, F.; Fardoun, F.; Biwole, P.H. Phase change materials (PCM) for cooling applications in buildings: A review. Energy Build. 2016, 129, 396-431. [CrossRef]

12. Agyenim, F.; Hewitt, N.; Eames, P.; Smyth, M. A review of materials, heat transfer and phase change problem formulation for latent heat thermal energy storage systems (LHTESS). Renew. Sustain. Energy Rev. 2010, 14, 615-628. [CrossRef]

13. Jegadheeswaran, S.; Pohekar, S.D. Performance enhancement in latent heat thermal storage system: A review. Renew. Sustain. Energy Rev. 2009, 13, 2225-2244. [CrossRef]

14. Sharma, A.; Tyagi, V.V.; Chen, C.R.; Buddhi, D. Review on thermal energy storage with phase change materials and applications. Renew. Sustain. Energy Rev. 2009, 13, 318-345. [CrossRef]

15. Mondal, S. Phase change materials for smart textiles-An overview. Appl. Therm. Eng. 2008, 28, 1536-1550. [CrossRef]

16. Farid, M.M.; Khudhair, A.M.; Razack, S.A.K.; Al-Hallaj, S. A review on phase change energy storage: Materials and applications. Energy Convers. Manag. 2004, 45, 1597-1615. [CrossRef]

17. Zalba, B.; Marin, J.M.; Cabeza, L.F.; Mehling, H. Review on thermal energy storage with phase change: Materials, heat transfer analysis and applications. Appl. Therm. Eng. 2003, 23, 251-283. [CrossRef]

18. Alva, G.; Lin, Y.; Fang, G. An overview of thermal energy storage systems. Energy 2018, 144, $341-378$. [CrossRef]

19. Wu, Y.; Chen, C.; Jia, Y.; Wu, J.; Huang, Y.; Wang, L. Review on electrospun ultrafine phase change fibers (PCFs) for thermal energy storage. Appl. Energy 2018, 210, 167-181. [CrossRef]

20. Lin, Y.; Jia, Y.; Alva, G.; Fang, G. Review on thermal conductivity enhancement, thermal properties and applications of phase change materials in thermal energy storage. Renew. Sustain. Energy Rev. 2018, 82, 2730-2742. [CrossRef]

21. Liu, M.; Saman, W.; Bruno, F. Review on storage materials and thermal performance enhancement techniques for high temperature phase change thermal storage systems. Renew. Sustain. Energy Rev. 2012, 16, 2118-2132. [CrossRef] 
22. Gil, A.; Medrano, M.; Martorell, I.; Lázaro, A.; Dolado, P.; Zalba, B.; Cabeza, L.F. State of the art on high temperature thermal energy storage for power generation. Part 1 -Concepts, materials and modellization. Renew. Sustain. Energy Rev. 2010, 14, 31-55. [CrossRef]

23. Medrano, M.; Gil, A.; Martorell, I.; Potau, X.; Cabeza, L.F. State of the art on high-temperature thermal energy storage for power generation. Part 2-Case studies. Renew. Sustain. Energy Rev. 2010, 14, 56-72. [CrossRef]

24. Kenisarin, M.M. High-temperature phase change materials for thermal energy storage. Renew. Sustain. Energy Rev. 2010, 14, 955-970. [CrossRef]

25. Wei, G.; Wang, G.; Xu, C.; Ju, X.; Xing, L.; Du, X.; Yang, Y. Selection principles and thermophysical properties of high temperature phase change materials for thermal energy storage: A review. Renew. Sustain. Energy Rev. 2018, 81, 1771-1786. [CrossRef]

26. Kenisarin, M.; Mahkamov, K. Solar energy storage using phase change materials. Renew. Sustain. Energy Rev. 2007, 11, 1913-1965. [CrossRef]

27. Shukla, A.; Buddhi, D.; Sawhney, R.L. Solar water heaters with phase change material thermal energy storage medium: A review. Renew. Sustain. Energy Rev. 2009, 13, 2119-2125. [CrossRef]

28. Hasnain, S.M. Review on sustainable thermal energy storage technologies, Part I: Heat storage materials and techniques. Energy Convers. Manag. 1998, 39, 1127-1138. [CrossRef]

29. Reddy, K.S.; Mudgal, V.; Mallick, T.K. Review of latent heat thermal energy storage for improved material stability and effective load management. J. Energy Storage 2018, 15, 205-227. [CrossRef]

30. Pandey, A.K.; Hossain, M.S.; Tyagi, V.V.; Rahim, N.A.; Jeyraj, A.; Selvaraj, L.; Sari, A. Novel approaches and recent developments on potential applications of phase change materials in solar energy. Renew. Sustain. Energy Rev. 2018, 82, 281-323. [CrossRef]

31. Regin, A.F.; Solanki, S.C.; Saini, J.S. Heat transfer characteristics of thermal energy storage system using PCM capsules: A review. Renew. Sustain. Energy Rev. 2008, 12, 2438-2458. [CrossRef]

32. Salunkhe, P.B.; Shembekar, P.S. A review on effect of phase change material encapsulation on the thermal performance of a system. Renew. Sustain. Energy Rev. 2012, 16, 5603-5616. [CrossRef]

33. Oró, E.; De Gracia, A.; Castell, A.; Farid, M.M.; Cabeza, L.F. Review on phase change materials (PCMs) for cold thermal energy storage applications. Appl. Energy 2012, 99, 513-533. [CrossRef]

34. Kenisarin, M.; Mahkamov, K. Passive thermal control in residential buildings using phase change materials. Renew. Sustain. Energy Rev. 2016, 55, 371-398. [CrossRef]

35. Kalnæs, S.E.; Jelle, B.P. Phase change materials and products for building applications: A state-of-the-art review and future research opportunities. Energy Build. 2015, 94, 150-176. [CrossRef]

36. Memon, S.A. Phase change materials integrated in building walls: A state of the art review. Renew. Sustain. Energy Rev. 2014, 31, 870-906. [CrossRef]

37. Tatsidjodoung, P.; Le Pierrès, N.; Luo, L. A review of potential materials for thermal energy storage in building applications. Renew. Sustain. Energy Rev. 2013, 18, 327-349. [CrossRef]

38. Soares, N.; Costa, J.J.; Gaspar, A.R.; Santos, P. Review of passive PCM latent heat thermal energy storage systems towards buildings' energy efficiency. Energy Build. 2013, 59, 82-103. [CrossRef]

39. Pomianowski, M.; Heiselberg, P.; Zhang, Y. Review of thermal energy storage technologies based on PCM application in buildings. Energy Build. 2013, 67, 56-69. [CrossRef]

40. Rodriguez-Ubinas, E.; Ruiz-Valero, L.; Vega, S.; Neila, J. Applications of phase change material in highly energy-efficient houses. Energy Build. 2012, 50, 49-62. [CrossRef]

41. Pasupathy, A.; Velraj, R. Phase change material based thermal storage for energy conservation in building architecture. Int. Energy J. 2006, 7, 147-159.

42. Zhou, D.; Zhao, C.Y.; Tian, Y. Review on thermal energy storage with phase change materials (PCMs) in building applications. Appl. Energy 2012, 92, 593-605. [CrossRef]

43. Rao, Z.; Wang, S.; Zhang, Z. Energy saving latent heat storage and environmental friendly humiditycontrolled materials for indoor climate. Renew. Sustain. Energy Rev. 2012, 16, 3136-3145. [CrossRef]

44. Cabeza, L.F.; Castell, A.; Barreneche, C.; De Gracia, A.; Fernández, A.I. Materials used as PCM in thermal energy storage in buildings: A review. Renew. Sustain. Energy Rev. 2011, 15, 1675-1695. [CrossRef]

45. Kuznik, F.; David, D.; Johannes, K.; Roux, J.J. A review on phase change materials integrated in building walls. Renew. Sustain. Energy Rev. 2011, 15, 379-391. [CrossRef]

46. Baetens, R.; Jelle, B.P.; Gustavsen, A. Phase change materials for building applications: A state-of-the-art review. Energy Build. 2010, 42, 1361-1368. [CrossRef] 
47. Zhu, N.; Ma, Z.; Wang, S. Dynamic characteristics and energy performance of buildings using phase change materials: A review. Energy Convers. Manag. 2009, 50, 3169-3181. [CrossRef]

48. Wang, X.; Zhang, Y.; Xiao, W.; Zeng, R.; Zhang, Q.; Di, H. Review on thermal performance of phase change energy storage building envelope. Chin. Sci. Bull. 2009, 54, 920-928. [CrossRef]

49. Pasupathy, A.; Velraj, R.; Seeniraj, R.V. Phase change material-based building architecture for thermal management in residential and commercial establishments. Renew. Sustain. Energy Rev. 2008, 12, $39-64$. [CrossRef]

50. Tyagi, V.V.; Buddhi, D. PCM thermal storage in buildings: A state of art. Renew. Sustain. Energy Rev. 2007, 11, 1146-1166. [CrossRef]

51. Zhang, Y.; Zhou, G.; Lin, K.; Zhang, Q.; Di, H. Application of latent heat thermal energy storage in buildings: State-of-the-art and outlook. Build. Environ. 2007, 42, 2197-2209. [CrossRef]

52. Khudhair, A.M.; Farid, M.M. A review on energy conservation in building applications with thermal storage by latent heat using phase change materials. Energy Convers. Manag. 2004, 45, 263-275. [CrossRef]

53. Kürklü, A. Energy storage applications in greenhouses by means of phase change materials (PCMs): A review. Renew. Energy 1998, 13, 89-103. [CrossRef]

54. Song, M.; Niu, F.; Mao, N.; Hu, Y.; Deng, S. Review on building energy performance improvement using phase change materials. Energy Build. 2018, 158, 776-793. [CrossRef]

55. Rao, V.V.; Parameshwaran, R.; Ram, V.V. PCM-mortar based construction materials for energy efficient buildings: A review on research trends. Energy Build. 2018, 158, 95-122. [CrossRef]

56. Akeiber, H.; Nejat, P.; Majid, M.Z.A.; Wahid, M.A.; Jomehzadeh, F.; Famileh, I.Z.; Calautit, J.K.; Hughes, B.R.; Zaki, S.A. A review on phase change material (PCM) for sustainable passive cooling in building envelopes. Renew. Sustain. Energy Rev. 2016, 60, 1470-1497. [CrossRef]

57. Waqas, A.; Din, Z.U. Phase change material (PCM) storage for free cooling of buildings-A review. Renew. Sustain. Energy Rev. 2013, 18, 607-625. [CrossRef]

58. Raj, V.A.A.; Velraj, R. Review on free cooling of buildings using phase change materials. Renew. Sustain. Energy Rev. 2010, 14, 2819-2829. [CrossRef]

59. Osterman, E.; Tyagi, V.V.; Butala, V.; Rahim, N.A.; Stritih, U. Review of PCM based cooling technologies for buildings. Energy Build. 2012, 49, 37-49. [CrossRef]

60. Oropeza-Perez, I.; Østergaard, P.A. Active and passive cooling methods for dwellings: A review. Renew. Sustain. Energy Rev. 2018, 82, 531-544. [CrossRef]

61. Zeinelabdein, R.; Omer, S.; Gan, G. Critical review of latent heat storage systems for free cooling in buildings. Renew. Sustain. Energy Rev. 2018, 82, 2843-2868. [CrossRef]

62. AL-Saadi, S.N.; Zhai, Z.J. Modeling phase change materials embedded in building enclosure: A review. Renew. Sustain. Energy Rev. 2013, 21, 659-673. [CrossRef]

63. Dutil, Y.; Rousse, D.R.; Salah, N.B.; Lassue, S.; Zalewski, L. A review on phase-change materials: Mathematical modeling and simulations. Renew. Sustain. Energy Rev. 2011, 15, 112-130. [CrossRef]

64. Verma, P.; Singal, S.K. Review of mathematical modeling on latent heat thermal energy storage systems using phase-change material. Renew. Sustain. Energy Rev. 2008, 12, 999-1031. [CrossRef]

65. Konuklu, Y.; Ostry, M.; Paksoy, H.O.; Charvat, P. Review on using microencapsulated phase change materials (PCM) in building applications. Energy Build. 2015, 106, 134-155. [CrossRef]

66. Tyagi, V.V.; Kaushik, S.C.; Tyagi, S.K.; Akiyama, T. Development of phase change materials based microencapsulated technology for buildings: A review. Renew. Sustain. Energy Rev. 2011, 15, 1373-1391. [CrossRef]

67. Rathod, M.K.; Banerjee, J. Thermal stability of phase change materials used in latent heat energy storage systems: A review. Renew. Sustain. Energy Rev. 2013, 18, 246-258. [CrossRef]

68. Fan, L.; Khodadadi, J.M. Thermal conductivity enhancement of phase change materials for thermal energy storage: A review. Renew. Sustain. Energy Rev. 2011, 15, 24-46. [CrossRef]

69. Ling, T.C.; Poon, C.S. Use of phase change materials for thermal energy storage in concrete: An overview. Constr. Build. Mater. 2013, 46, 55-62. [CrossRef]

70. Ukrainczyk, N.; Kurajica, S.; Šipušić, J. Thermophysical comparison of five commercial paraffin waxes as latent heat storage materials. Chem. Biochem. Eng. Q. 2010, 24, 129-137. 
71. Sarı, A.; Karaipekli, A. Thermal conductivity and latent heat thermal energy storage characteristics of paraffin/expanded graphite composite as phase change material. Appl. Therm. Eng. 2007, 27, 1271-1277. [CrossRef]

72. Hawes, D.W.; Banu, D.; Feldman, D. Latent heat storage in concrete. Sol. Energy Mater. 1989, 19, $335-348$. [CrossRef]

73. Hawes, D. Latent Heat Storage in Concrete. Ph.D. Thesis, Concordia University, Montreal, QC, Canada, 1991.

74. Hawes, D.W.; Banu, D.; Feldman, D. The stability of phase change materials in concrete. Sol. Energy Mater. Sol. Cells 1992, 27, 103-118. [CrossRef]

75. Feldman, D.; Banu, D.; Hawes, D.W. Development and application of organic phase change mixtures in thermal storage gypsum wallboard. Sol. Energy Mater. Sol. Cells 1995, 36, 147-157. [CrossRef]

76. Eddhahak-Ouni, A.; Drissi, S.; Colin, J.; Neji, J.; Care, S. Experimental and multi-scale analysis of the thermal properties of Portland cement concretes embedded with microencapsulated Phase Change Materials (PCMs). Appl. Therm. Eng. 2014, 64, 32-39. [CrossRef]

77. Cao, V.D.; Pilehvar, S.; Salas-Bringas, C.; Szczotok, A.M.; Rodriguez, J.F.; Carmona, M.; Al-Manasir, N.; Kjøniksen, A.L. Microencapsulated phase change materials for enhancing the thermal performance of Portland cement concrete and geopolymer concrete for passive building applications. Energy Convers. Manag. 2017, 133, 56-66. [CrossRef]

78. Fernandes, F.; Manari, S.; Aguayo, M.; Santos, K.; Oey, T.; Wei, Z.; Falzone, G.; Neithalath, N.; Sant, G. On the feasibility of using phase change materials (PCMs) to mitigate thermal cracking in cementitious materials. Cem. Concr. Compos. 2014, 51, 14-26. [CrossRef]

79. Cheng, R.; Pomianowski, M.; Wang, X.; Heiselberg, P.; Zhang, Y. A new method to determine thermophysical properties of PCM-concrete brick. Appl. Energy 2013, 112, 988-998. [CrossRef]

80. Entrop, A.G.; Brouwers, H.J.H.; Reinders, A.H.M.E. Experimental research on the use of micro-encapsulated phase change materials to store solar energy in concrete floors and to save energy in Dutch houses. Sol. Energy 2011, 85, 1007-1020. [CrossRef]

81. Hunger, M.; Entrop, A.G.; Mandilaras, I.; Brouwers, H.J.H.; Founti, M. The behavior of self-compacting concrete containing micro-encapsulated phase change materials. Cem. Concr. Compos. 2009, 31, 731-743. [CrossRef]

82. Cabeza, L.F.; Castellon, C.; Nogues, M.; Medrano, M.; Leppers, R.; Zubillaga, O. Use of microencapsulated PCM in concrete walls for energy savings. Energy Build. 2007, 39, 113-119. [CrossRef]

83. Ramakrishnan, S.; Sanjayan, J.; Wang, X.; Alam, M.; Wilson, J. A novel paraffin/expanded perlite composite phase change material for prevention of PCM leakage in cementitious composites. Appl. Energy 2015, 157, 85-94. [CrossRef]

84. Cellat, K.; Beyhan, B.; Güngör, C.; Konuklu, Y.; Karahan, O.; Dündar, C.; Paksoy, H. Thermal enhancement of concrete by adding bio-based fatty acids as phase change materials. Energy Build. 2015, 106, 156-163. [CrossRef]

85. Shi, X.; Memon, S.A.; Tang, W.; Cui, H.; Xing, F. Experimental assessment of position of macro encapsulated phase change material in concrete walls on indoor temperatures and humidity levels. Energy Build. 2014, 71, 80-87. [CrossRef]

86. Alqallaf, H.J.; Alawadhi, E.M. Concrete roof with cylindrical holes containing PCM to reduce the heat gain. Energy Build. 2013, 61, 73-80. [CrossRef]

87. Castell, A.; Martorell, I.; Medrano, M.; Pérez, G.; Cabeza, L.F. Experimental study of using PCM in brick constructive solutions for passive cooling. Energy Build. 2010, 42, 534-540. [CrossRef]

88. Hadjieva, M.; Stoykov, R.; Filipova, T.Z. Composite salt-hydrate concrete system for building energy storage. Renew. Energy 2000, 19, 111-115. [CrossRef]

89. Zhang, D.; Li, Z.; Zhou, J.; Wu, K. Development of thermal energy storage concrete. Cem. Concr. Res. 2004, 34, 927-934. [CrossRef]

90. Nepomuceno, M.C.; Silva, P.D. Experimental evaluation of cement mortars with phase change material incorporated via lightweight expanded clay aggregate. Constr. Build. Mater. 2014, 63, 89-96. [CrossRef]

91. Sakulich, A.R.; Bentz, D.P. Incorporation of phase change materials in cementitious systems via fine lightweight aggregate. Constr. Build. Mater. 2012, 35, 483-490. [CrossRef]

92. Bentz, D.P.; Turpin, R. Potential applications of phase change materials in concrete technology. Cem. Concr. Compos. 2007, 29, 527-532. [CrossRef] 
93. Carslaw, H.S.; Jaeger, J.C. Conduction of Heat in Solids, 2nd ed.; Oxford Science Publications: Oxford, UK, 1988.

94. Crank, J. Free and Moving Boundary Problems; Oxford University Press: Oxford, UK, 1984.

95. Lamberg, P. Approximate analytical model for two-phase solidification problem in a finned phase-change material storage. Appl. Energy 2004, 77, 131-152. [CrossRef]

96. Lamberg, P.; Siren, K. Analytical model for melting in a semi-infinite PCM storage with an internal fin. Heat Mass Transf. 2003, 39, 167-176. [CrossRef]

97. Voller, V.R.; Swenson, J.B.; Paola, C. An analytical solution for a Stefan problem with variable latent heat. Int. J. Heat Mass Transf. 2004, 47, 5387-5390. [CrossRef]

98. Mazzeo, D.; Oliveti, G. Parametric study and approximation of the exact analytical solution of the Stefan problem in a finite PCM layer in a steady periodic regime. Int. Commun. Heat Mass Transf. 2017, 84, 49-65. [CrossRef]

99. Heydari, B.; Talati, F. Numerical solution of heat transfer process in PCM storage using Tau method. Math. Probl. Eng. 2015, 2015, 805641. [CrossRef]

100. Alexiades, V. Mathematical Modeling of Melting and Freezing Processes; CRC Press: Boca Raton, FL, USA, 1992.

101. Mirzaei, P.A.; Haghighat, F. Modeling of phase change materials for applications in whole building simulation. Renew. Sustain. Energy Rev. 2012, 16, 5355-5362. [CrossRef]

102. Voller, V.R.; Prakash, C. A fixed grid numerical modelling methodology for convection-diffusion mushy region phase-change problems. Int. J. Heat Mass Transf. 1987, 30, 1709-1719. [CrossRef]

103. Voller, V.R.; Cross, M.; Markatos, N.C. An enthalpy method for convection/diffusion phase change. Int. J. Numer. Methods Eng. 1987, 24, 271-284. [CrossRef]

104. Koller, M.; Walter, H.; Hameter, M. Transient Numerical Simulation of the Melting and Solidification Behavior of $\mathrm{NaNO}_{3}$ Using a Wire Matrix for Enhancing the Heat Transfer. Energies 2016, 9, 205. [CrossRef]

105. Solomon, L.; Elmozughi, A.F.; Oztekin, A.; Neti, S. Effect of internal void placement on the heat transfer performance-Encapsulated phase change material for energy storage. Renew. Energy 2015, 78, 438-447. [CrossRef]

106. Souayfane, F.; Fardoun, F.; Biwole, P.H. Different mathematical models of convection during phase change. In Proceedings of the 2016 3rd International Conference on Renewable Energies for Developing Countries (REDEC), Zouk Mosbeh, Lebanon, 13-15 July 2016; pp. 1-8.

107. Sciacovelli, A.; Colella, F.; Verda, V. Melting of PCM in a thermal energy storage unit: Numerical investigation and effect of nanoparticle enhancement. Int. J. Energy Res. 2013, 37, 1610-1623. [CrossRef]

108. Beckermann, C.; Diepers, H.J.; Steinbach, I.; Karma, A.; Tong, X. Modeling melt convection in phase-field simulations of solidification. J. Comput. Phys. 1999, 154, 468-496. [CrossRef]

109. Alawadhi, E.M. Phase change process with free convection in a circular enclosure: Numerical simulations. Comput. Fluids 2004, 33, 1335-1348. [CrossRef]

110. Alawadhi, E.M. Thermal analysis of a pipe insulation with a phase change material: Material selection and sizing. Heat Transf. Eng. 2008, 29, 624-631. [CrossRef]

111. Eyres, N.R.; Hartree, D.R.; Ingham, J.; Jackson, R.; Sarjant, R.J.; Wagstaff, J.B. The calculation of variable heat flow in solids. Philos. Trans. R. Soc. Lond. Ser. A Math. Phys. Sci. 1946, 240, 1-57. [CrossRef]

112. Price, P.H.; Slack, M.R. The effect of latent heat on numerical solutions of the heat flow equation. Br. J. Appl. Phys. 1954, 5, 285. [CrossRef]

113. Voller, V.; Cross, M. Accurate solutions of moving boundary problems using the enthalpy method. Int. J. Heat Mass Transf. 1981, 24, 545-556. [CrossRef]

114. Lynch, D.R.; O'Neill, K. Continuously deforming finite elements for the solution of parabolic problems, with and without phase change. Int. J. Numer. Methods Eng. 1981, 17, 81-96. [CrossRef]

115. Lynch, D.R. Unified approach to simulation on deforming elements with application to phase change problems. J. Comput. Phys. 1982, 47, 387-411. [CrossRef]

116. Udaykumar, H.S.; Mittal, R.; Shyy, W. Computation of solid-liquid phase fronts in the sharp interface limit on fixed grids. J. Comput. Phys. 1999, 153, 535-574. [CrossRef]

117. Voller, V.R. An implicit enthalpy solution for phase change problems: With application to a binary alloy solidification. Appl. Math. Model. 1987, 11, 110-116. [CrossRef]

118. Voller, V.R.; Swaminathan, C.R.; Thomas, B.G. Fixed grid techniques for phase change problems: A review. Int. J. Numer. Methods Eng. 1990, 30, 875-898. [CrossRef] 
119. Swaminathan, C.R.; Voller, V.R. On the enthalpy method. Int. J. Numer. Methods Heat Fluid Flow 1993, 3, 233-244. [CrossRef]

120. McAdie, R.L.; Cross, J.T.; Lewis, R.W.; Gethin, D.T. A finite element enthalpy technique for solving coupled nonlinear heat conduction/mass diffusion problems with phase change. Int. J. Numer. Methods Heat Fluid Flow 1995, 5, 907-921. [CrossRef]

121. Costa, M.; Buddhi, D.; Oliva, A. Numerical simulation of a latent heat thermal energy storage system with enhanced heat conduction. Energy Convers. Manag. 1998, 39, 319-330. [CrossRef]

122. Zivkovic, B.; Fujii, I. An analysis of isothermal phase change of phase change material within rectangular and cylindrical containers. Sol. Energy 2001, 70, 51-61. [CrossRef]

123. Bhattacharya, M.; Basak, T.; Ayappa, K.G. A fixed-grid finite element based enthalpy formulation for generalized phase change problems: Role of superficial mushy region. Int. J. Heat Mass Transf. 2002, 45, 4881-4898. [CrossRef]

124. Nedjar, B. An enthalpy-based finite element method for nonlinear heat problems involving phase change. Comput. Struct. 2002, 80, 9-21. [CrossRef]

125. Silva, P.D.; Goncalves, L.C.; Pires, L. Transient behaviour of a latent-heat thermal-energy store: Numerical and experimental studies. Appl. Energy 2002, 73, 83-98. [CrossRef]

126. Esen, A.; Kutluay, S. A numerical solution of the Stefan problem with a Neumann-type boundary condition by enthalpy method. Appl. Math. Comput. 2004, 148, 321-329. [CrossRef]

127. Lamberg, P.; Lehtiniemi, R.; Henell, A.M. Numerical and experimental investigation of melting and freezing processes in phase change material storage. Int. J. Therm. Sci. 2004, 43, 277-287. [CrossRef]

128. Vyshak, N.R.; Jilani, G. Numerical analysis of latent heat thermal energy storage system. Energy Convers. Manag. 2007, 48, 2161-2168. [CrossRef]

129. Izquierdo-Barrientos, M.A.; Belmonte, J.F.; Rodríguez-Sánchez, D.; Molina, A.E.; Almendros-Ibáñez, J.A. A numerical study of external building walls containing phase change materials (PCM). Appl. Therm. Eng. 2012, 47, 73-85. [CrossRef]

130. Kong, X.; Lu, S.; Li, Y.; Huang, J.; Liu, S. Numerical study on the thermal performance of building wall and roof incorporating phase change material panel for passive cooling application. Energy Build. 2014, 81, 404-415. [CrossRef]

131. Li, D.; Zheng, Y.; Liu, C.; Wu, G. Numerical analysis on thermal performance of roof contained PCM of a single residential building. Energy Convers. Manag. 2015, 100, 147-156. [CrossRef]

132. Kumar, A.; Kumar, S.; Katiyar, V.K.; Telles, S. Phase change heat transfer during cryosurgery of lung cancer using hyperbolic heat conduction model. Comput. Biol. Med. 2017, 84, 20-29. [CrossRef] [PubMed]

133. Lopez, J.P.A.; Kuznik, F.; Baillis, D.; Virgone, J. Numerical modeling and experimental validation of a PCM to air heat exchanger. Energy Build. 2013, 64, 415-422. [CrossRef]

134. Bonacina, C.; Comini, G.; Fasano, A.; Primicerio, M. Numerical solution of phase-change problems. Int. J. Heat Mass Transf. 1973, 16, 1825-1832. [CrossRef]

135. Idelsohn, S.R.; Storti, M.A.; Crivelli, L.A. Numerical methods in phase-change problems. Arch. Comput. Methods Eng. 1994, 1, 49-74. [CrossRef]

136. Voller, V.R. An overview of numerical methods for solving phase change problems. Adv. Numer. Heat Transf. 1997, 1, 341-380.

137. Pasupathy, A.; Velraj, R. Effect of double layer phase change material in building roof for year round thermal management. Energy Build. 2008, 40, 193-203. [CrossRef]

138. Pasupathy, A.; Athanasius, L.; Velraj, R.; Seeniraj, R.V. Experimental investigation and numerical simulation analysis on the thermal performance of a building roof incorporating phase change material (PCM) for thermal management. Appl. Therm. Eng. 2008, 28, 556-565. [CrossRef]

139. Zhang, D.; Fung, A.S.; Siddiqui, O. Finite element modeling for integrated solid-solid PCM-building material with varying phase change temperatures. In Proceedings of the 3rd SBRN and SESCI 33rd Joint Conference, Frederickton, NB, Canada, 20-22 August 2008; pp. 1-8.

140. Fang, Y.; Medina, M.A. Proposed modifications for models of heat transfer problems involving partially melted phase change processes. J. ASTM Int. 2009, 6, 1-20. [CrossRef]

141. Thiele, A.M.; Sant, G.; Pilon, L. Diurnal thermal analysis of microencapsulated PCM-concrete composite walls. Energy Convers. Manag. 2015, 93, 215-227. [CrossRef] 
142. Šavija, B.; Schlangen, E. Use of phase change materials (PCMs) to mitigate early age thermal cracking in concrete: Theoretical considerations. Constr. Build. Mater. 2016, 126, 332-344. [CrossRef]

143. Hu, H.; Argyropoulos, S.A. Mathematical modelling of solidification and melting: A review. Model. Simul. Mater. Sci. Eng. 1996, 4, 371. [CrossRef]

144. Samarskii, A.A.; Vabishchevivh, P.N. Computational Heat Transfer. Mathematical Modelling; Wiley: Hoboken, NJ, USA, 1995; Volume 1.

145. Heim, D.; Clarke, J.A. Numerical modelling and thermal simulation of PCM-gypsum composites with ESP-r. Energy Build. 2004, 36, 795-805. [CrossRef]

146. Heim, D. Isothermal storage of solar energy in building construction. Renew. Energy 2010, 35, 788-796. [CrossRef]

147. Zukowski, M. Mathematical modeling and numerical simulation of a short term thermal energy storage system using phase change material for heating applications. Energy Convers. Manag. 2007, 48, 155-165. [CrossRef]

148. Mankel, C.; Caggiano, A.; Ukrainczyk, N.; Koenders, E.A.B. Thermal energy storage characterization of cement-based systems containing Microencapsulated-PCMs. Constr. Build. Mater. 2019, 199, 307-320. [CrossRef]

149. Evola, G.; Marletta, L.; Sicurella, F. A methodology for investigating the effectiveness of PCM wallboards for summer thermal comfort in buildings. Build. Environ. 2013, 59, 517-527. [CrossRef]

150. Thiele, A.M.; Wei, Z.; Falzone, G.; Young, B.A.; Neithalath, N.; Sant, G.; Pilon, L. Figure of merit for the thermal performance of cementitious composites containing phase change materials. Cem. Concr. Compos. 2016, 65, 214-226. [CrossRef]

151. Tittelein, P.; Gibout, S.; Franquet, E.; Johannes, K.; Zalewski, L.; Kuznik, F.; Dumas, J.P.; Lassue, S.; Bédécarrats, J.P.; David, D. Simulation of the thermal and energy behaviour of a composite material containing encapsulated-PCM: Influence of the thermodynamical modelling. Appl. Energy 2015, 140, 269-274. [CrossRef]

152. Kheradmand, M.; Azenha, M.; de Aguiar, J.L.; Castro-Gomes, J. Experimental and numerical studies of hybrid PCM embedded in plastering mortar for enhanced thermal behaviour of buildings. Energy 2016, 94, 250-261. [CrossRef]

153. Yao, C.; Kong, X.; Li, Y.; Du, Y.; Qi, C. Numerical and experimental research of cold storage for a novel expanded perlite-based shape-stabilized phase change material wallboard used in building. Energy Convers. Manag. 2018, 155, 20-31. [CrossRef]

154. Young, B.A.; Falzone, G.; Wei, Z.; Sant, G.; Pilon, L. Reduced-scale experiments to evaluate performance of composite building envelopes containing phase change materials. Constr. Build. Mater. 2018, 162, 584-595. [CrossRef]

155. Singh, S.P.; Bhat, V. Performance evaluation of dual phase change material gypsum board for the reduction of temperature swings in a building prototype in composite climate. Energy Build. 2018, 159, 191-200. [CrossRef]

156. Han, C.; Yu, X.B. An innovative energy pile technology to expand the viability of geothermal bridge deck snow melting for different United States regions: Computational assisted feasibility analyses. Renew. Energy 2018, 123, 417-427. [CrossRef]

157. Voller, V.R. Implicit finite-difference solutions of the enthalpy formulation of Stefan problems. IMA J. Numer. Anal. 1985, 5, 201-214. [CrossRef]

158. Swaminathan, C.R.; Voller, V.R. Towards a general numerical scheme for solidification systems. Int. J. Heat Mass Transf. 1997, 40, 2859-2868. [CrossRef]

159. Fachinotti, V.D.; Cardona, A.; Huespe, A.E. A fast convergent and accurate temperature model for phase-change heat conduction. Int. J. Numer. Methods Eng. 1999, 44, 1863-1884. [CrossRef]

160. Brusche, J.H.; Segal, A.; Vuik, C.; Urbach, H.P. A Comparison of Enthalpy and Temperature Methods for Melting Problems on Composite Domains. In Numerical Mathematics and Advanced Applications; Springer: Berlin/Heidelberg, Germany, 2006; pp. 585-592.

161. Rostamizadeh, M.; Khanlarkhani, M.; Sadrameli, S.M. Simulation of energy storage system with phase change material (PCM). Energy Build. 2012, 49, 419-422. [CrossRef]

162. Athukorallage, B.; Dissanayaka, T.; Senadheera, S.; James, D. Performance analysis of incorporating phase change materials in asphalt concrete pavements. Constr. Build. Mater. 2018, 164, 419-432. [CrossRef] 
163. Heim, D. Two solution methods of heat transfer with phase change within whole building dynamic simulation. In Proceedings of the 9th International IBPSA Conference, Montréal, QC, Canada, 15-18 August 2005.

164. Evola, G.; Marletta, L.; Sicurella, F. Simulation of a ventilated cavity to enhance the effectiveness of PCM wallboards for summer thermal comfort in buildings. Energy Build. 2014, 70, 480-489. [CrossRef]

165. Ibanez, M.; Lázaro, A.; Zalba, B.; Cabeza, L.F. An approach to the simulation of PCMs in building applications using TRNSYS. Appl. Therm. Eng. 2005, 25, 1796-1807. [CrossRef]

166. Lu, S.; Liu, S.; Huang, J.; Kong, X. Establishment and experimental verification of PCM room's TRNSYS heat transfer model based on latent heat utilization ratio. Energy Build. 2014, 84, 287-298. [CrossRef]

167. Al-Saadi, S.N.; Zhai, Z.J. A new validated TRNSYS module for simulating latent heat storage walls. Energy Build. 2015, 109, 274-290. [CrossRef]

168. Kalagasidis, A.S.; Weitzmann, P.; Nielsen, T.R.; Peuhkuri, R.; Hagentoft, C.E.; Rode, C. The international building physics toolbox in Simulink. Energy Build. 2007, 39, 665-674. [CrossRef]

169. Al-Saadi, S.N. Modeling and Simulation of PCM-Enhanced Façade Systems. Ph.D. Dissertation, University of Colorado at Boulder, Boulder, CO, USA, 2014.

170. Sasic Kalagasidis, A. A multi-level modelling and evaluation of thermal performance of phase-change materials in buildings. J. Build. Perform. Simul. 2014, 7, 289-308. [CrossRef]

171. El Mankibi, M.; Zhai, Z.J.; Al-Saadi, S.N.; Zoubir, A. Numerical modeling of thermal behaviors of active multi-layer living wall. Energy Build. 2015, 106, 96-110. [CrossRef]

172. Kosny, J. PCM-Enhanced Building Components: An Application of Phase Change Materials in Building Envelopes and Internal Structures; Springer: Berlin, Germany, 2015.

173. Al-Saadi, S.N.; Zhai, Z.J. Systematic evaluation of mathematical methods and numerical schemes for modeling PCM-enhanced building enclosure. Energy Build. 2015, 92, 374-388. [CrossRef]

174. Dumas, J.P.; Gibout, S.; Zalewski, L.; Johannes, K.; Franquet, E.; Lassue, S.; Bédécarrats, J.P.; Tittelein, P.; Kuznik, F. Interpretation of calorimetry experiments to characterise phase change materials. Int. J. Therm. Sci. 2014, 78, 48-55. [CrossRef]

175. Zhu, N.; Hu, P.; Xu, L. A simplified dynamic model of double layers shape-stabilized phase change materials wallboards. Energy Build. 2013, 67, 508-516. [CrossRef]

176. Zhu, N.; Liu, F.; Liu, P.; Hu, P.; Wu, M. Energy saving potential of a novel phase change material wallboard in typical climate regions of China. Energy Build. 2016, 128, 360-369. [CrossRef]

177. Zhang, Y.; Huang, B.; Li, D.X. Finite Element Analysis of the Heat Transfer Problems of PCMs. Mater. Sci. Forum 2013, 743/744, 216-221. [CrossRef]

178. Kousksou, T.; Arid, A.; Jamil, A.; Zeraouli, Y. Thermal behavior of building material containing microencapsulated PCM. Thermochim. Acta 2012, 550, 42-47. [CrossRef]

179. Franquet, E.; Gibout, S.; Tittelein, P.; Zalewski, L.; Dumas, J.P. Experimental and theoretical analysis of a cement mortar containing microencapsulated PCM. Appl. Therm. Eng. 2014, 73, 32-40. [CrossRef]

180. Faheem, A.; Ranzi, G.; Fiorito, F.; Lei, C. A numerical study on the thermal performance of night ventilated hollow core slabs cast with micro-encapsulated PCM concrete. Energy Build. 2016, 127, 892-906. [CrossRef]

181. Pei, H.; Li, Z.; Li, Y. Early-age shrinkage and temperature optimization for cement paste by using PCM and $\mathrm{MgO}$ based on FBG sensing technique. Constr. Build. Mater. 2016, 117, 58-62. [CrossRef]

182. Arora, A.; Sant, G.; Neithalath, N. Numerical simulations to quantify the influence of Phase Change Materials (PCMs) on the early-and later-age thermal response of concrete pavements. Cem. Concr. Compos. 2017, 81, 11-24. [CrossRef]

183. Young, B.A.; Falzone, G.; She, Z.; Thiele, A.M.; Wei, Z.; Neithalath, N.; Sant, G.; Pilon, L. Early-age temperature evolutions in concrete pavements containing microencapsulated phase change materials. Constr. Build. Mater. 2017, 147, 466-477. [CrossRef]

184. Felske, J.D. Effective thermal conductivity of composite spheres in a continuous medium with contact resistance. Int. J. Heat Mass Transf. 2004, 47, 3453-3461. [CrossRef]

185. Thiele, A.M.; Kumar, A.; Sant, G.; Pilon, L. Effective thermal conductivity of three-component composites containing spherical capsules. Int. J. Heat Mass Transf. 2014, 73, 177-185. [CrossRef]

186. Ricklefs, A.; Thiele, A.M.; Falzone, G.; Sant, G.; Pilon, L. Thermal conductivity of cementitious composites containing microencapsulated phase change materials. Int. J. Heat Mass Transf. 2017, 104, 71-82. [CrossRef] 
187. Böhm, H.J.; Nogales, S. Mori-Tanaka models for the thermal conductivity of composites with interfacial resistance and particle size distributions. Compos. Sci. Technol. 2008, 68, 1181-1187. [CrossRef]

188. Stránský, J.; Vorel, J.; Zeman, J.; Šejnoha, M. Mori-Tanaka based estimates of effective thermal conductivity of various engineering materials. Micromachines 2011, 2, 129-149. [CrossRef]

189. Aguayo, M.; Das, S.; Castro, C.; Kabay, N.; Sant, G.; Neithalath, N. Porous inclusions as hosts for phase change materials in cementitious composites: Characterization, thermal performance, and analytical models. Constr. Build. Mater. 2017, 134, 574-584. [CrossRef]

190. Mandilaras, I.D.; Kontogeorgos, D.A.; Founti, M.A. A hybrid methodology for the determination of the effective heat capacity of PCM enhanced building components. Renew. Energy 2015, 76, 790-804. [CrossRef]

191. Aguayo, M.; Das, S.; Maroli, A.; Kabay, N.; Mertens, J.C.; Rajan, S.D.; Sant, G.; Chawla, N.; Neithalath, N. The influence of microencapsulated phase change material (PCM) characteristics on the microstructure and strength of cementitious composites: Experiments and finite element simulations. Cem. Concr. Compos. 2016, 73, 29-41. [CrossRef]

192. Mohaine, S.; Feliu, J.; Grondin, F.; Karkri, M.; Loukili, A. Multiscale modelling for the thermal creep analysis of PCM concrete. Energy Build. 2016, 131, 99-112. [CrossRef]

193. Young, B.A.; Wei, Z.; Rubalcava-Cruz, J.; Falzone, G.; Kumar, A.; Neithalath, N.; Sant, G.; Pilon, L. A general method for retrieving thermal deformation properties of microencapsulated phase change materials or other particulate inclusions in cementitious composites. Mater. Des. 2017, 126, 259-267. [CrossRef]

194. Schicchi, D.S.; Caggiano, A.; Hunkel, M.; Koenders, E.A.B. Thermodynamically consistent multiscale formulation of a thermo-mechanical problem with phase transformations. Contin. Mech. Thermodyn. 2018, 1-27. [CrossRef]

(C) 2018 by the authors. Licensee MDPI, Basel, Switzerland. This article is an open access article distributed under the terms and conditions of the Creative Commons Attribution (CC BY) license (http:/ / creativecommons.org/licenses/by/4.0/). 